\title{
Microdistribution of interstitial meiofauna, oxygen and sulfide gradients, and the tubes of macro-infauna
}

\author{
Mark B. Meyers ${ }^{1, *}$, Henrik Fossing ${ }^{2} \&$ Eric N. Powell ${ }^{1, * *}$ \\ ${ }^{1}$ Department of Oceanography, Texas A \& M University, College Station, Texas 77843, USA \\ ${ }^{2}$ Institute of Ecology and Genetics, University of Aarhus, Ny Munkegade, DK-8000 Aarhus C, Denmark
}

\begin{abstract}
Vertical and horizontal micro-scale gradients of oxygen and sulfide and meiofaunal distributions were examined concurrently in laboratory microcosms to assess the importance of tube/ burrow wall chemistry in generating microhabitat for subsurface meiofauna. These distributions were compared to field distributions at a subtidal site in Corpus Christi Bay, Texas (USA). Results reveal a continuum of microhabitats across oxygen and sulfide gradients in marine sands. The majority of taxa lived at $\left[\mathrm{O}_{2}\right]$ below $50 \mu \mathrm{M}$. These included microoxyphilic oxybiota living at $\left[\mathrm{O}_{2}\right]>0$ and thiobiota at $\left[\mathrm{O}_{2}\right]=0$. All classic thiobiota lived below the zero-oxygen line where sediments usually contained measurable sulfide. Most, but not all, subsurface taxa were attracted to burrows/tubes; however, only 1 taxon, Praeaphanostoma, lived in the microoxyphilic habitat of the burrow/tube wall's oxic halo. The remainder lived outside this zone where $\left[\mathrm{O}_{2}\right]=0$. No dominant species had substantially overlapping distributions. Each abundant species occupied its own unique microhabitat. Most microhabitat boundaries could be explained by changes in $\mathrm{O}_{2}$ and sulfide concentration; however, a few taxa were differentially distributed in microhabitats of similar chemistry, suggesting that other factors were important. Changing sediment chemistry may remove or create optimal microhabitat seasonally so that taxa must be able to exploit a range of suboptimal habitats to survive throughout the year. Most microhabitats, in shortest dimension, were no more than 2 to 3 times the animal's size, suggesting that traverses of no more than a few body lengths would be necessary to move from optimal to suboptimal habitat. Overall, the complex distributional patterns of meiofaunal species suggest that Fenchel \& Riedl's (1970) simple 2-layered model of marine sand bottoms, comprising a surface oxic layer and a sulfide system, is inadequate. Even taxa living where $\left[\mathrm{O}_{2}\right]=0$ were distributed differentially along the sulfide gradient. Whether thiobiota and oxybiota are merely 2 ends of a continuum or really ecologically relevant subsets of subsurface meiofauna must be reconsidered.
\end{abstract}

\section{INTRODUCTION}

Most shallow marine sandy sediments consist of an upper oxic zone and a deeper anoxic, sulfide-rich zone separated by a chemocline. The sulfide system as defined by Fenchel \& Riedl (1970) comprises the chemocline and underlying anoxic zone. Fenchel \& Riedl listed a variety of metazoan taxa having representatives in this biotope. Later investigations demonstrated that certain groups such as the Gnathostomulida and, among the Turbellaria, the Solenofilomorphidae and Catenulida, were regularly

\footnotetext{
- Present address: Department of Marine Science, University of South Florida, St. Petersburg, Florida 33701, USA

- Addressee for reprint requests
}

found only in subsurface sediment (Boaden \& Platt 1971, Sterrer \& Rieger 1974, Crezee 1976, Farris \& Lindgren 1984).

Fenchel \& Riedl's (1970) description depicted a relatively simple 2-layered structure for marine sands, the sulfide system overlain by oxic sediment. Boaden \& Platt (1971) termed inhabitants of the sulfide system, thiobios. Powell et al. (1983) termed inhabitants of the oxic sediment, oxybios. At the time of the original description, the existence of thiobios was remarkable because sulfide was generally considered to be toxic to all Metazoa and the lack of oxygen inimical to metazoan life (Boaden 1975, 1977).

Since 1970, results from 2 important areas of investigation substantially modified Fenchel \& Riedl's (1970) original view. First, many taxa, including macrofaunal 
taxa, tolerate or require sulfide (e.g. Powell et al. 1980 Felbeck 1981, Felbeck et al. 1981, 1983, Giere et al 1982), sulfide detoxification capabilities are widespread among these taxa (Powell et al. 1979, Nuss 1984, Powell \& Somero 1985), and at least a few metazoans prefer anoxia to high (seawater-saturated) oxygen concentrations (Wieser et al. 1974, Baker et al. 1985, Famme \& Knudsen 1985). Second, marine sediments are not simple 2-layer systems but are replete with microhabitats generated predominately by macro-infauna (Reise 1981a,b, 1984, Bell 1983). Consequently, much consideration has been given to how subsurface meiofauna are distributed within these microhabitats; 2 alternatives have been advanced. Reise \& Ax (1979) proposed that most subsurface meiofaunal taxa occupied the oxic halo around burrows' tubes. Such taxa would be aerobic and sulfide-intolerant. No thiobiota would exist. Thus, Fenchel \& Riedl's 2-layer model would be explained by the presence of a surface biota and a subsurface burrow/tube-associated biota. Powell \& Bright (1981) suggested that the chemocline around burrows/tubes was preferentially inhabited by thiobiota exploiting a relatively food-rich area. Typically, bacterial biomass and production are enhanced around these structures (Fenchel \& Jørgensen 1977, Aller \& Yingst 1978, 1985, Alongi 1985). Such taxa would be sulfide-tolerant biota, thiobiota as defined by Powell \& Bright (1981). Thus Fenchel \& Riedl's 2-layer model would be explained by a surface oxybiota and a subsurface thiobiota exploiting both horizontal and vertical chemoclines.

These differing explanations for the observed vertical distributions of meiofauna result primarily from the technological difficulty of making chemical measurements on a scale pertinent to the animals (Fenchel 1978), a scale of millimeters to microns in both horizontal and vertical dimensions. Recent advances in microelectrode technology have substantiated the importance of making measurements on this scale (Jørgensen et al. 1979, Revsbech et al. 1980). Consequently, we chose to examine the microdistribution of subsurface meiofauna vis-à-vis horizontal and vertical chemoclines using microelectrodes to test the hypotheses presented by Reise \& Ax (1979) and Powell $\&$ Bright (1981). The study consisted of 2 components: a descriptive field study to document faunal distributions and an experimental study using laboratory microcosms to investigate these distributional patterns in more detail.

\section{MATERIALS AND METHODS}

Field studies. A moderate energy, subtidal site located on a sand bar in Corpus Christi Bay, Texas
(USA), about $100 \mathrm{~m}$ northeast of Fish Pass, was chosen for sampling. During July 1984, cores were taken with a $2.1 \mathrm{~cm}$ diameter plastic syringe corer and sectioned vertically into intervals of $1.0 \mathrm{~mm}$ in the top $1.0 \mathrm{~cm}$ and $1.0 \mathrm{~cm}$ thereafter down to $10.0 \mathrm{~cm}$ depth. Thirty cores were taken, 5 each for $6 \mathrm{~d}$. Local tides are minimal and predominantly wind-driven; water depth at the site varied from 25 to $95 \mathrm{~cm}$ during this period. Concurrently, and again in November 1984, samples with small polychaete burrows and tubes were taken and divided into (1) burrow/tube wall; (2) sediment immediately adjacent (within 2 to $4 \mathrm{~mm}$ ) to the wall; (3) gray sediment at least $1.0 \mathrm{~cm}$ away from the wall. Sections from 5 to 10 similar burrows or tubes were combined in the field and analyzed as a composite sample.

Additional samples were taken periodically over the following $9 \mathrm{mo}$. On each occasion, an area of $0.25 \mathrm{~m}^{2}$ was randomly sampled with 10 to 20 cores $12.1 \mathrm{~cm}$ diameter, $10 \mathrm{~cm}$ deep). Observations were made on each core regarding the depth of the chemocline as evidenced by a visual change in sediment color and on the presence of macrofaunal polychaetes, their burrows/tubes, or of any subsurface oxidized patches.

All core samples were extracted for meiofauna by $\mathrm{MgCl}_{2}$ decantation (Crezee 1976) using a $63 \mu \mathrm{m}$ mesh, and sieved through a $500 \mu \mathrm{m}$ screen for polychaetes and tubes. Meiofaunal individuals in the phyla Platyhelminthes, Gastrotricha, and Gnathostomulida were identified, usually to species, and enumerated.

Laboratory microcosm experiments. Field distributions, if controlled by the distribution of burrows, are unlikely to be at equilibrium because burrows/tubes are constantly made and destroyed and burrow chemistry is constantly modified by changes in animal behavior modulated by biological and physical processes (Aller et aI. 1983, Aller 1984). To obtain a more controlled system, we experimented with polychaetes in aquaria, but polychaete behavior was too unpredictable even under controlled conditions. Consequently, we chose to use artificial tubes in aquaria to obtain stable chemical conditions over many days. Aquaria were $20 \mathrm{~cm}$ wide and $0.5 \mathrm{~cm}$ thick with one removable side (Fig. 1). Each was filled with natural sediment collected at the Corpus Christi Bay site, the top $4 \mathrm{~cm}$ of which was sieved $(500 \mu \mathrm{m})$ to remove shell debris in order to minimize the chances of damaging the microelectrodes. The aquaria were then buried in sediment in larger tanks to prevent light from penetrating beyond the sediment surface. The overlying seawater was continuously bubbled with air

Simulated polychaete tubes were constructed using a glass capillary tube placed inside of dialysis tubing (Spectrapor \#1), which was supported by glass tubing at either end and sealed at the bottom (Fig. 1A). A 


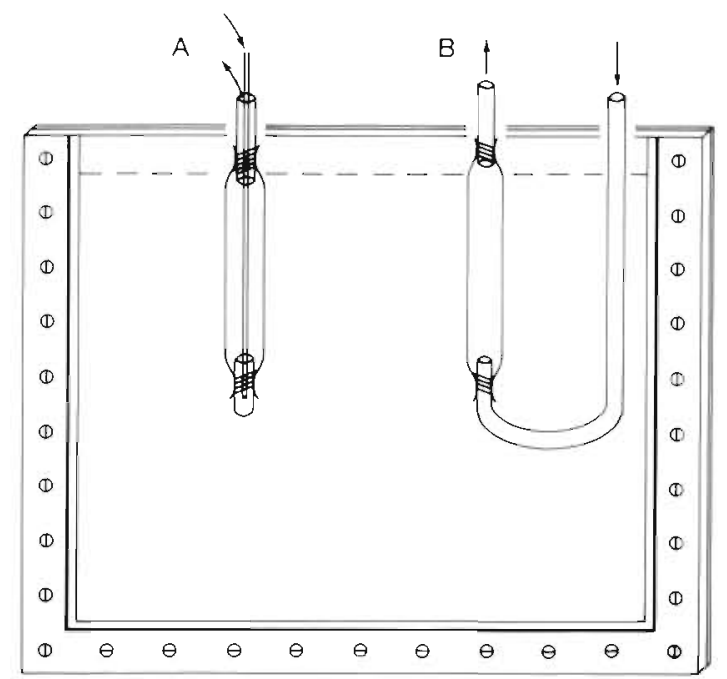

Fig. 1. Aquarium used in distribution experiments; removable side held in place by plastic screws and sealed with O-ring material. A: Simulated polychaete tube used in most experiments; B: modified tube design used in time-course analyses of chemical gradients to avoid microelectrode breakage during measurements close to tube wall. Aquaria were filled with natural sediment up to dashed line

peristaltic pump passed seawater through the capillary tube to the bottom of the assembly. The outflow flowed back to the surface through the outer dialysis tube. Two artificial tubes were used per aquarium, only one of which was irrigated. The other served as a control. In some cases, where microelectrode measurements very near the tube wall were required, a modified tube (Fig. 1B) was used to eliminate the possibility of the microelectrode breaking on impact with the glass capillary.

Chemical profiling, when possible, was performed just prior to sampling of the aquaria. The sediment was divided into samples based on the oxygen and sulfide gradients (when available), on sediment color, and on the hypothesized microhabitats. Sampling of the aquaria took less than $15 \mathrm{~min}$. Abbreviations of sampling locations and of taxa are defined in Table 1. Each figure in which data are presented is accompanied by the sampling scheme for that experiment. After $\mathrm{MgCl}_{2}$ extraction, each sediment sample was dried and weighed.

Microelectrode analyses of oxygen and sulfide. All measurements were made at $22^{\circ} \mathrm{C}\left( \pm 1 \mathrm{C}^{\circ}\right)$ and $29 \mathrm{ppt}$ ( \pm 2 ppt)

Use and manufacture of oxygen and sulfide microelectrodes was described by Revsbech (1983) and Revsbech \& Ward $(1983,1984)$. The oxygen microelectrode consisted of a gold/platinum cathode housed inside a $\mathrm{Ag} / \mathrm{AgCl}$ reference and separated from the environment with a silicone membrane. The use of a gold-plated cathode prevented poisoning by sulfide. The tip was 2 to $5 \mu \mathrm{m}$ in diameter, allowing for submillimeter spatial resolution of oxygen. Linear calibration was made for each profile as described by

Table 1. Description of sampling protocol for aquaria used in distributional experiments and key to species abbreviations

\begin{tabular}{|c|c|}
\hline Sample & Comments \\
\hline \multicolumn{2}{|l|}{ Oxic layers } \\
\hline $\begin{array}{l}\mathrm{SFC} \\
\mathrm{SFC} 1, \mathrm{SFC} 2\end{array}$ & $\begin{array}{l}\text { Surface oxic layer, usually } 2 \text { to } 3 \mathrm{~mm} \text { deep; when divided horizontally, labelling was by number; when } \\
\text { divided vertically, lower layer was designated CLIN }\end{array}$ \\
\hline $\begin{array}{l}\text { CLIN } \\
\text { CLIN1, CLIN2 }\end{array}$ & $\begin{array}{l}\text { Subsurface sediment exclusive of tube where a transitional color change occurred between yellow } \\
\text { surface and darker gray sediments or, if chemical measurements were available, the zone where } \mathrm{O}_{2} \\
\text { gradient was sharp. Typically, ranged between } 2 \text { to } 10 \mathrm{~mm} \text { thick and included zero-oxygen line. }\end{array}$ \\
\hline $\begin{array}{l}\text { FLOW, NFLO } \\
\text { AFLOW, ANFLO } \\
\text { BFLOW, BNFLO }\end{array}$ & $\begin{array}{l}\text { Irrigated (FLOW) or unirrigated (NFLO) tubes. Tube } A=\text { tube on left-hand side of aquarium. Tube } B= \\
\text { tube on right-hand side of aquarium. Size of sample taken around both tubes correspond to extent of } \\
\text { oxic halo around irrigated tube, ca } 2 \text { to } 3 \mathrm{~mm}\end{array}$ \\
\hline \multicolumn{2}{|l|}{ Anoxic layers } \\
\hline $\begin{array}{l}\text { GRA } \\
\text { GRA1, GRA2, } \\
\text { GRA3, GRA4 }\end{array}$ & $\begin{array}{l}\text { Gray sediment, within depth zone of the tubes }(\mathrm{ca} 6 \text { to } 7 \mathrm{~cm}) \text { sometimes divided laterally into ADJ and } \\
\text { GRA layers. Numbers indicate lateral subdividions of aquarium into halves or quarters }\end{array}$ \\
\hline $\begin{array}{l}\text { ADJ } \\
\text { ADJA, ADJB }\end{array}$ & $\begin{array}{l}\text { Region just outside oxic halo of an irrigated tube or equivalently sized sample around unirrigated tube. } \\
\text { FLOW/ADJ boundary approximated the zero-oxygen line around irrigated tube (ca } 2.0 \mathrm{~mm} \text { thick) }\end{array}$ \\
\hline DEEP & Sediment below depth of the tubes (below ca $7 \mathrm{~cm}$ ) \\
\hline \multicolumn{2}{|c|}{$\begin{array}{l}\text { Key to species: Kuma = Kuma sp.; Prae = Praeaphanostoma sp; Para = Parahaploposthia thiophilus (= Pseudohaplogonaria } \\
\text { sp. of Crezee 1976); Sole = Solenofilomorpha cf. funilis; Myop = Myopea sp.; Typhlo = Typhloplanoida; Kalypt = } \\
\text { Kalyptorhynchia; Mono = Monocelididae sp.; Coelo = Coelogynoporidae sp.; Turb = Turbanella ocellata }(=\text { Turbanella sp. } \\
\text { of Fox \& Powell 1986b); Gnatho = Gnathostomulida; Macro = Macrostomum hystricinum; Poly = Polychaeta }\end{array}$} \\
\hline
\end{tabular}


Revsbech \& Ward (1983) using the anoxic pore water below the oxygen gradient as zero and oxygen saturated seawater as the second value. The sulfide electrode was a $\mathrm{Ag} / \mathrm{Ag}_{2} \mathrm{~S}$ electrode (Berner 1963) with a detection limit of about $20 \mu \mathrm{M}$ total dissolved sulfide $\left(\mathrm{H}_{2} \mathrm{~S}, \mathrm{HS}^{-}, \mathrm{S}^{2-}\right)$ at typical pore water $\mathrm{pH}$ 's $(\mathrm{pH}$ may vary from 7 to 9 in near surface sediments; Revsbech et al. 1983). Measurements of $\mathrm{pH}$ on complementary scales $(<1.0 \mathrm{~mm})$ required the use of a $\mathrm{pH}$ microelectrode, which was too fragile to use in our sandy sediments. Thus, the measurement of sulfide was limited to determining presence/absence by setting an effective detection limit to $-550 \mathrm{mV}$ of electrode potential. This potential was chosen because (1) the electrode response to sulfide became nonlinear at lower concentrations (Fig. 2); (2) at typical sediment $\mathrm{pH}$ values, this

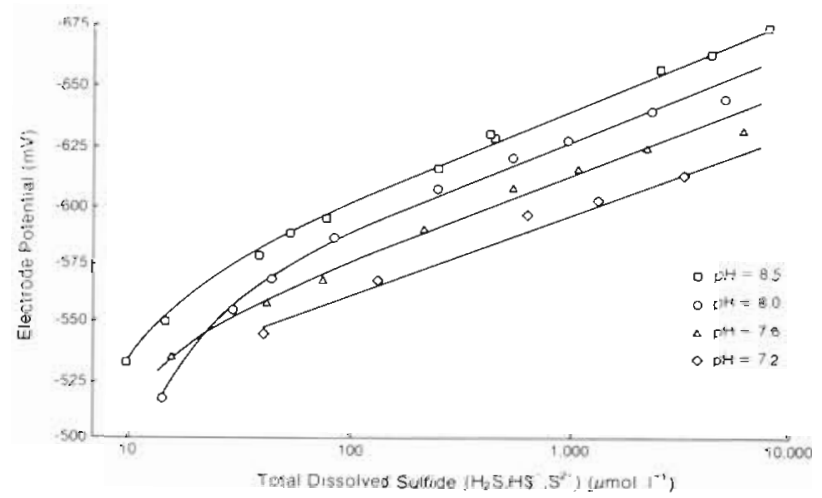

Fig. 2. Response of sulfide microelectrode to varying sulfide concentrations at $4 \mathrm{pH}$ levels

potential equated with a total dissolved sulfide concentration of 20 to $80 \mu \mathrm{M}$, the upper range for the thiobiotic/oxybiotic boundary observed by Powell et al. (1983). Hence, this potential represents a conservative estimate of the area impacted by sulfide. A calornel electrode was used as reference.

Oxygen microelectrodes were connected to a Keithley 485 picoammeter and to a stable $750 \mathrm{mV}$ power supply. Sulfide microelectrodes were connected to a Cole-Parmer Digiphase $14 \mathrm{pH}$ meter.

\section{RESULTS}

\section{Field distribution}

Thirty-three species of turbellarians, 5 species of gnathostomulids, and 4 species of gastrotrichs were collected at the Corpus Christi Bay site (Table 2). Dominant turbellarians included Praeaphanostoma sp., Parahaploposthia thiophilus, and Solenofilomorpha cf. funilis, all of which are Acoela. The most abundant species overall was the gastrotrich Turbanella ocellata.

More than two-thirds of these species had $>80 \%$ of their populations below the chemocline (as deduced from the depth where sediment color changed) $(\sim 0.5$ to $1.0 \mathrm{~cm}$ ) (Table 3). Most of those that did not - including Macrostomum hystricinum, the Dalyellioida, the Typhloplanoida and Monocelididae sp. - are typical surface oxybiota (Crezee 1976). Overall, however, classic surface oxybiota, as reported in the literature, were poorly represented at our site. In contrast, the typically deeper-living, so-called thiobiotic species dominated the assemblage ( $\sim 80 \%$ of all individuals).

Three general patterns of species distribution were evident, as illustrated in a cluster analysis dendrogram (Fig. 3) for the data collected in July. Some taxa occurred primarily in the upper few $\mathrm{cm}$, the surface component (III); some occurred primarily beneath but close to

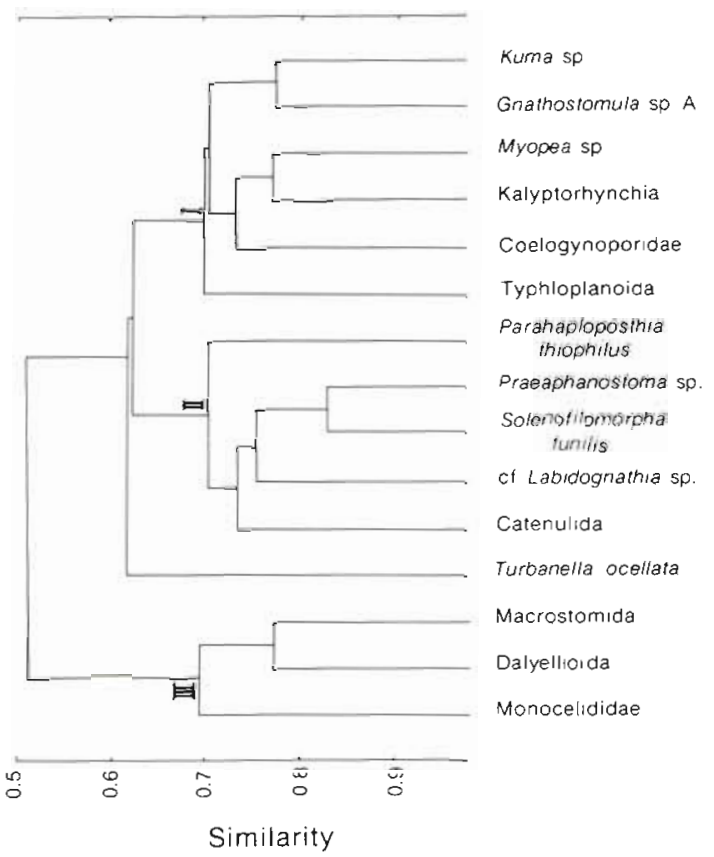

Fig. 3. Cluster analysis dendrogram for taxa collected in July. Raw data listed in Table 3

the chemocline, in the upper $\sim 5 \mathrm{~cm}$ (I); others occurred beneath the chemocline and frequently down to at least $10 \mathrm{~cm}$ depth (II). Turbanella ocellata - because of its abundance over a broad depth range - was related to, but not distinctly a part of, either of the 2 subsurface groups (I, II).

Results of targeted burrow and tube samplings are presented in Tables 4 and 5. The surface sample (SFC) is in reality 0 to $1.0 \mathrm{~cm}$ deep. Other samples were taken from depths of 2 to $7 \mathrm{~cm}$. The 'thin tubes', about $2 \mathrm{~mm}$ 
Table 2. Meiofauna species found at collecting site Corpus Christi Bay, Texas (USA). Numbers are individuals per $100 \mathrm{~cm}^{3}$

\begin{tabular}{|c|c|c|c|c|c|c|c|c|}
\hline Meiofauna & Jul & Aug & Sep & Oct & Nov & Jan & Feb & Apr \\
\hline \multicolumn{9}{|l|}{ PLATYHELMINTHES } \\
\hline \multicolumn{9}{|l|}{$\overline{\text { Catenulida }}$} \\
\hline \multicolumn{9}{|l|}{ Retronectes sp. A (reddish-brown) } \\
\hline Retronectes sp. B (black \& white) & 11 & 8 & 6 & 6 & 7 & 5 & 2 & 2 \\
\hline Retronectes sp. C (white) & & & & & & & & \\
\hline \multicolumn{9}{|l|}{ Nemertodermatida } \\
\hline Nemertoderma sp. & & & & & & & & \\
\hline \multicolumn{9}{|l|}{ Acoela } \\
\hline \multicolumn{9}{|l|}{ Anaperidae } \\
\hline Anaperus sp. & & & & & & & 1 & 1 \\
\hline \multicolumn{9}{|l|}{ Convolutidae } \\
\hline Praeaphanostoma sp. & 76 & 162 & 26 & 31 & 47 & 71 & 40 & 296 \\
\hline Unid. sp. A & & & & $<1$ & & $<1$ & & 4 \\
\hline Unid. sp. B & & & & $<1$ & 2 & & 1 & 6 \\
\hline \multicolumn{9}{|l|}{ Haploposthiidae } \\
\hline Kuma sp. & 2 & 2 & 5 & 10 & 19 & 12 & 15 & 28 \\
\hline Parahaploposthia thiophilus & 13 & 14 & 15 & 46 & 60 & 64 & 62 & 86 \\
\hline Mecynostomidae (unid. sp.) & $<1$ & $<1$ & $<1$ & $<1$ & 2 & $<1$ & & \\
\hline \multicolumn{9}{|l|}{ Solenofilomorphidae } \\
\hline Myopea sp. & 3 & 1 & 4 & 4 & 1 & 9 & 10 & 10 \\
\hline Solenofilomorpha cf, funilis & 51 & 26 & 34 & 47 & 60 & 40 & 31 & 40 \\
\hline \multicolumn{9}{|l|}{ Macrostomida } \\
\hline Dolichomacrostomidae (unid. sp.) & & & 2 & 4 & 6 & $<1$ & 17 & 2 \\
\hline Macrostomum hystricinum & 30 & 30 & 17 & 23 & 1 & & & \\
\hline Dalyellioida (2 unid. spp.) & 8 & 2 & 5 & 2 & 7 & 1 & 2 & 3 \\
\hline \multicolumn{9}{|l|}{ Typhloplanoida } \\
\hline cf. Kytorhynchella sp. & $<1$ & & & & & & 1 & 3 \\
\hline Promesostoma sp. & 2 & 1 & 3 & 1 & 2 & $<1$ & 1 & 1 \\
\hline Messoplana cf. falcata & & & & & 1 & 1 & 5 & 15 \\
\hline Typhloplanidae (3 unid. spp.) & $<1$ & 1 & $<1$ & & 1 & & 2 & 2 \\
\hline \multicolumn{9}{|l|}{ Kalyptorhynchia } \\
\hline Unid. sp. & $<1$ & & & & & & $<1$ & \\
\hline Cheliplanilla sp. & & & 1 & 1 & 2 & $<1$ & 4 & 2 \\
\hline Karkinorhynchidae (unid. sp.) & & & & $<1$ & 1 & 1 & 4 & 22 \\
\hline Proschizorhynchus sp & 1 & 1 & 2 & 3 & 1 & 1 & 1 & 1 \\
\hline Schizorhynchidae ( 3 unid. spp.) & $<1$ & 1 & & $<1$ & 2 & $<1$ & 3 & $\hat{5}$ \\
\hline \multicolumn{9}{|l|}{ Proseriata } \\
\hline Coelogynoporidae (unid. sp.) & 1 & 3 & 1 & 3 & 4 & 2 & 5 & 8 \\
\hline Monocelididae (unid. sp.) & 2 & 2 & 1 & 9 & 2 & & 1 & 1 \\
\hline Nematoplanidae (unid. sp.) ${ }^{*}$ & & & & & & & & \\
\hline \multicolumn{9}{|l|}{ GNATHOSTOMULIDA } \\
\hline Gnathostomula sp. A & 40 & 49 & 11 & 24 & 9 & 3 & $<1$ & $<1$ \\
\hline Gnathostomula sp. B" & & & & & & & & \\
\hline cf. Labidognathia sp. & 15 & 12 & 7 & 4 & 4 & 2 & 2 & 1 \\
\hline Austrognathiidae sp. & $<1$ & & & & & & & \\
\hline Filospermoidea (unid. sp.) & & & & $<1$ & & & $<1$ & \\
\hline \multicolumn{9}{|l|}{ GASTROTRICHA } \\
\hline Turbanella ocellata & 179 & 122 & 116 & 130 & 82 & 81 & 217 & 197 \\
\hline cf. Dolichodasys sp. & & & $<1$ & $<1$ & & $<1$ & 1 & $<1$ \\
\hline cf. Macrodasys sp. & & & & & & & $<1$ & $<1$ \\
\hline Neodasys sp. & & & & & $<1$ & $<1$ & 2 & 2 \\
\hline
\end{tabular}

diameter, were constructed by paraonid, orbiniid and spionid polychaetes and were made of sand grains cemented together. Diopatra cuprea tubes on the other hand were much larger (about $1 \mathrm{~cm}$ diameter) parch- ment-like constructions reinforced at the sedimentwater interface with shell debris and sand grains (Defretin 1971, Myers 1972). The oxidized sand sample from November 1984 was a patch of yellow-brown 
Table 3. Vertical distribution of meiofauna on a subtidal sand bar, Corpus Christi Bay, Texas, Jul 1984. Numbers are individuals in a total of 30 cores $\left(34.6 \mathrm{~cm}^{3}\right.$ each). Depths indicate bottom of each interval

\begin{tabular}{|c|c|c|c|c|c|c|c|c|c|c|c|c|c|c|c|c|c|c|c|c|}
\hline \multicolumn{21}{|c|}{ Sample depth $(\mathrm{cm})$} \\
\hline Taxon & 0.1 & 0.2 & 0.3 & 0.4 & 0.5 & 0.6 & 0.7 & 0.8 & 0.9 & 1.0 & 2.0 & 3.0 & 4.0 & 5.0 & 6.0 & 7.0 & 8.0 & 9.0 & 10.0 & Total \\
\hline Unid. acoel & 0 & 1 & 1 & 2 & 4 & 1 & 2 & 1 & 5 & 2 & 19 & 3 & 7 & 4 & 0 & 2 & 0 & 0 & 1 & 55 \\
\hline Kuma sp. & 0 & 1 & 0 & 0 & 0 & 0 & 0 & 0 & 0 & 0 & 8 & 0 & 2 & 0 & 0 & 0 & 0 & 0 & 0 & 11 \\
\hline Parahaploposthia thiophilus & 0 & 0 & 4 & 5 & 6 & 5 & 6 & 2 & 0 & 7 & 24 & 18 & 26 & 11 & 6 & 5 & 0 & 3 & 7 & 135 \\
\hline Praeaphanostoma sp. & 1 & 1 & 2 & 0 & 0 & 0 & 0 & 1 & 1 & 2 & 204 & 101 & 130 & 76 & 47 & 50 & 54 & 24 & 55 & 749 \\
\hline Myopea sp. & 0 & 0 & 0 & 2 & 1 & 2 & 0 & 0 & 0 & 1 & 2 & 1 & 6 & 4 & 6 & 2 & 0 & 0 & 0 & 27 \\
\hline Solenofilomorpha cf. funilis & 3 & 0 & 4 & 8 & 1 & 6 & 2 & 2 & 0 & 14 & 76 & 37 & 90 & 66 & 45 & 52 & 31 & 35 & 35 & 507 \\
\hline Catenulida & 2 & 0 & : & 1 & 1 & 0 & 1 & 0 & 0 & 3 & 7 & 3 & 8 & 8 & 9 & 24 & 8 & 17 & 24 & 117 \\
\hline Macrostomum hystricinum & 9 & 19 & 15 & 25 & 44 & 29 & 26 & 21 & 37 & 21 & 55 & 3 & 2 & 3 & 1 & 1 & 0 & 0 & 0 & 311 \\
\hline Dalyellooida & 2 & 6 & 4 & 3 & 8 & 10 & 4 & 8 & 11 & 4 & 34 & 1 & 4 & 2 & 0 & 0 & 2 & 1 & 0 & 104 \\
\hline Typhloplanoida & 0 & 6 & 0 & 1. & 4 & 1 & 1 & 1 & 0 & 1 & 5 & 1 & 0 & 1 & 3 & 0 & 0 & 0 & 0 & 25 \\
\hline Kalyptorhynchia & 0 & 0 & 0 & 0 & 1 & 0 & 0 & 0 & 0 & 0 & 1 & 5 & 2 & 3 & 0 & 0 & 1 & 0 & 0 & 13 \\
\hline Monocelididae & 2 & 2 & 9 & 0 & 4 & 1 & 4 & 3 & 1 & 0 & 0 & 2 & 0 & 1 & 0 & 0 & 0 & 0 & 1 & 30 \\
\hline Coelogynoporidae & 0 & 0 & 0 & 1 & 0 & 0 & 0 & 0 & 0 & 0 & 1 & 0 & 0 & 0 & 0 & 0 & 1 & 0 & 0 & 3 \\
\hline Turbanella ocellata & 1 & 6 & 1 & 10 & 35 & 47 & 68 & 65 & 55 & 246 & 439 & 421 & 452 & 148 & 61 & 30 & 19 & 36 & 34 & 2174 \\
\hline Gnathostomula sp. A & 0 & 0 & 0 & 1 & 1 & 4 & 4 & 7 & 7 & 18 & 149 & 51 & 33 & 15 & 8 & 0 & 3 & 2 & 3 & 306 \\
\hline cf Labidognathia sp. & 0 & 0 & 0 & 0 & 0 & 2 & 0 & 0 & 0 & 1 & 16 & 26 & 17 & 12 & $q$ & 4 & 4 & 3 & 10 & 104 \\
\hline Total & 20 & 42 & 41 & 59 & 110 & 108 & 118 & 111 & 117 & 320 & 1040 & 673 & 779 & 354 & 195 & 170 & 123 & 121 & 170 & 4671 \\
\hline Percent & 0.4 & 0.9 & 0.9 & 1.3 & 2.4 & 2.3 & 2.5 & 2.4 & 2.5 & 6.8 & 22.3 & 14.4 & 16.7 & 7.6 & 4.2 & 3.6 & 2.6 & 2.6 & 3.6 & \\
\hline Cum. percent & & 1.3 & 2.2 & 3.5 & 5.9 & 8.2 & 10.7 & 13.1 & 15.6 & 22.4 & 44.7 & 59.1 & 75.8 & 83.4 & 87.5 & 91.2 & 93.8 & 96.4 & 100.0 & \\
\hline
\end{tabular}

Table 4. Polychaete burrow and tube samples from a subtidal sand bar, Corpus Christi Bay, Texas, Jul 1984. Each column represents a composite sample obtained from collection and dissection of 5 to 10 tubes/burrows, reported as numbers of individuals per $10 \mathrm{~g}$ sediment. Weight is dry weight of composite sediment sample from which animals were obtained

\begin{tabular}{|c|c|c|c|c|c|}
\hline Sample & Burrows & Near burrows & Thin tubes & Diopatra tubes & Gray sand \\
\hline Weight $(g)$ & 20.1 & 18.2 & 14.0 & 91.2 & 54.7 \\
\hline Kuma sp. & 0 & 14 & 0 & & 0 \\
\hline Parahaploposthia thiophilus & 0 & 1 & 5 & 2 & 0 \\
\hline Praeaphanostoma sp. & 63 & 1 & 26 & 9 & 0 \\
\hline Solenofilomorpha cf. funilis & 14 & 0 & 4 & 27 & 1 \\
\hline Myopea sp. & 0 & 9 & 1 & $\cdot$ & $\cdot$ \\
\hline Catenulida & 0 & 3 & 1 & $\cdot$ & $\cdot$ \\
\hline Macrostomida & 0 & 2 & 1 & 0 & 0 \\
\hline Dalyellioida & 0 & 1 & 0 & $\cdot$ & 0 \\
\hline Typhloplanidae & 1 & 1 & 0 & 0 & 0 \\
\hline Kytorhynchidae & 0 & 0 & 0 & $\cdot$ & 0 \\
\hline Schizorhynchidae & 0 & 0 & 0 & $\cdot$ & 0 \\
\hline Monocelididae & 0 & 0 & 0 & $\cdot$ & $\cdot$ \\
\hline Coelogynoporidae & 1 & 0 & 2 & 0 & 1 \\
\hline Turbanella ocellata & 2 & 2 & 12 & 7 & 4 \\
\hline Neodasys sp. & 0 & 1 & 0 & 0 & $\cdot$ \\
\hline Gnathostomula sp. A & 7 & 3 & 9 & 3 & 1 \\
\hline cf. Labidognathia sp. & 1 & 1 & 0 & 1 & $\cdot$ \\
\hline
\end{tabular}

sand found several centimeters below the surface but not obviously associated with a polychaete burrow.

Burrow/tube microhabitats were an attractive location for many meiofaunal species. For example, Praeaphanostoma sp., Solenofilomorpha cf. funilis, and Gnathostomula sp. A were particularly abundant in burrow walls. Reduced sediment sampled more than
$2 \mathrm{~cm}$ away from any macrofaunal structure was relatively unattractive to meiofauna. Taxa that did have individuals in this region were Parahaploposthia thiophilus, both solenofilomorphid species, the catenulids, the coelogynoporid proseriate Turbanella ocellata, and the gnathostomulids. The oxidized sediment patch had greater concentrations of all taxa than 
Table 5. Polychaete burrow and tube samples from a subtidal sand bar, Corpus Christi Bay, Texas, Nov 1984. Each column represents a composite sediment sample obtained from collection and dissection of 5 to 10 tubes/burrows, reported as number of individuals per $10 \mathrm{~g}$ sediment. Weight is dry weight of composite sediment sample from which animals were obtained

\begin{tabular}{|c|c|c|c|c|c|c|c|c|c|}
\hline Sample & Burrows & $\begin{array}{c}\text { Near } \\
\text { burrows }\end{array}$ & Surface & $\begin{array}{l}\text { Thin } \\
\text { tubes }\end{array}$ & $\begin{array}{l}\text { Near } \\
\text { tubes }\end{array}$ & $\begin{array}{l}\text { Gray } \\
\text { sand }\end{array}$ & $\begin{array}{c}\text { Diopatra } \\
\text { tubes }\end{array}$ & $\begin{array}{c}\text { Near } \\
\text { Diopatra }\end{array}$ & $\begin{array}{l}\text { Oxidized } \\
\text { sand }\end{array}$ \\
\hline Weight (g) & 8.1 & 0.6 & 7.0 & 4.9 & 1.0 & 23.7 & 18.7 & 42.4 & 23.4 \\
\hline Kuma sp. & 0 & 17 & 0 & 0 & 10 & 0 & 0 & $\cdot$ & 1 \\
\hline Parahaplosthia thiophilus & 1 & 50 & 3 & 0 & 31 & $\cdot$ & 2 & 1 & 9 \\
\hline Praeaphanostoma sp. & 12 & 50 & 3 & 0 & 61 & 0 & 15 & 2 & 12 \\
\hline Solenofilomorpha cf. funilis & 3 & 0 & 1 & 6 & 245 & 0 & 6 & 8 & 3 \\
\hline Myopea sp. & 0 & 0 & 0 & 2 & 10 & 0 & 1 & $\cdot$ & $\cdot$ \\
\hline Catenulida & 1 & 0 & 0 & 0 & 0 & 0 & 1 & $\cdot$ & $\cdot$ \\
\hline Macrostomida & 6 & 0 & 7 & 0 & 0 & 0 & 2 & 0 & 1 \\
\hline Dalyellioida & 5 & 0 & 3 & 10 & 10 & 0 & 2 & 1 & $\cdot$ \\
\hline Typhloplanidae & 0 & 0 & 0 & 0 & 10 & 0 & 1 & $\cdot$ & 0 \\
\hline Promesostomidae & 0 & 0 & 6 & 0 & 10 & 0 & 1 & * & 0 \\
\hline Trigonostomidae & 0 & 0 & 0 & 0 & 0 & 0 & 1 & 0 & 0 \\
\hline Schizorhynchidae & 0 & 0 & 0 & 0 & 0 & 0 & 2 & 2 & 0 \\
\hline Karkinorhynchidae & 0 & 0 & 1 & 0 & 0 & 0 & 0 & 0 & 1 \\
\hline Monocelididae & 0 & 0 & 1 & 0 & 0 & 0 & 0 & 1 & 2 \\
\hline Coelogynoporidae & 0 & 0 & 0 & 0 & 0 & 0 & 1 & 1 & 0 \\
\hline Turbanella ocellata & 0 & 0 & 36 & 2 & 41 & 0 & 8 & 9 & 51 \\
\hline Gnathostomula sp. A & 5 & 0 & 0 & 0 & 92 & 0 & 30 & 12 & $\cdot$ \\
\hline cf. Labidognathia sp. & 1 & 0 & 0 & 0 & 41 & 0 & 0 & $\cdot$ & 0 \\
\hline
\end{tabular}

did reduced sediment taken from a similar depth. Turbanella ocellata, Praeaphanostoma sp., Parahaploposthia thiophilus, and Solenofilomorpha cf. funilis were especially abundant in this patch.

\section{Meiofaunal distributions in microcosms}

The results of 5 experiments (from Nov 1984, and Feb, Apr, May, and Jun 1985) will be used to illustrate the distributional patterns of meiofauna in the microcosms. Two uncontrollable factors influenced the results. Seasonal increases in meiofaunal abundance, especially among the Turbellaria, occurred between the November and February, and the April and June experiments. Turbellaria increased from about 210 to 540 per $100 \mathrm{~cm}^{3}$ between winter and spring. Consequently, taxon abundance and species composition changed with each experiment. Secondly, seasonal changes in temperature and in the abundance or activity of sulfate-reducing bacteria (Jørgensen 1977, Nedwell \& Abram 1978, Sørensen et al. 1979) resulted in greater sulfide production in sediments used during spring experiments than in those used during winter experiments. Consequently, the equilibrium chemical condition examined varied among experiments.

Irrigated tubes typically had a $3 \mathrm{~mm}$ oxic halo surrounding them once the gradients had stabilized. Isopleths of oxygen concentration were parallel to the tube wall except in the upper few $m$ m where some lateral spreading of the halo occurred. Oxygen concentration dropped from about $230 \mu \mathrm{M}$ in the tube's lumen (and at the surface) to $150 \mu \mathrm{M}$ within $250 \mu \mathrm{m}$ of the tube wall and $50 \mu \mathrm{M}$ within $1 \mathrm{~mm}$. Non-irrigated tubes had a microoxic halo of no more than $\sim 25 \mu \mathrm{M}$ extending out from the wall only $\sim 0.75 \mathrm{~mm}$ (Fig. 4) (compare Aller 1984, Ray \& Aller 1985). Time-course experiments showed that sediment chemistry stabilized within $24 \mathrm{~h}$ when sulfide production was low in winter (Fig. 5) and after about $4 \mathrm{~d}$ when sulfide production was high in summer. Time-course experiments (data not shown) indicated that both animal distributions and sediment chemistry remained stable for many days after equilibrium had been reached.

In the November 1984 experiment, the sediment appeared light gray with a weak color change beneath the surface layer, except for a distinct $3 \mathrm{~mm}$ thick, yellow-oxidized halo surrounding the irrigated tube. All turbellarians, except Parahaploposthia thiophilus, were found in the surface layer (SFC; this sample included part of the chemocline) (Fig. 6). P. thiophilus occurred beneath the chemocline, but was not attracted to the irrigated tube. Turbanella ocellata, Praeaphanostoma sp. and a kalyptorhynch were the only species found near the irrigated tube.

In February, the sediment appearance was similar to that in November. The acoel Praeaphanostoma sp. dominated the oxic halo around the irrigated tube and 
(A) Tube B

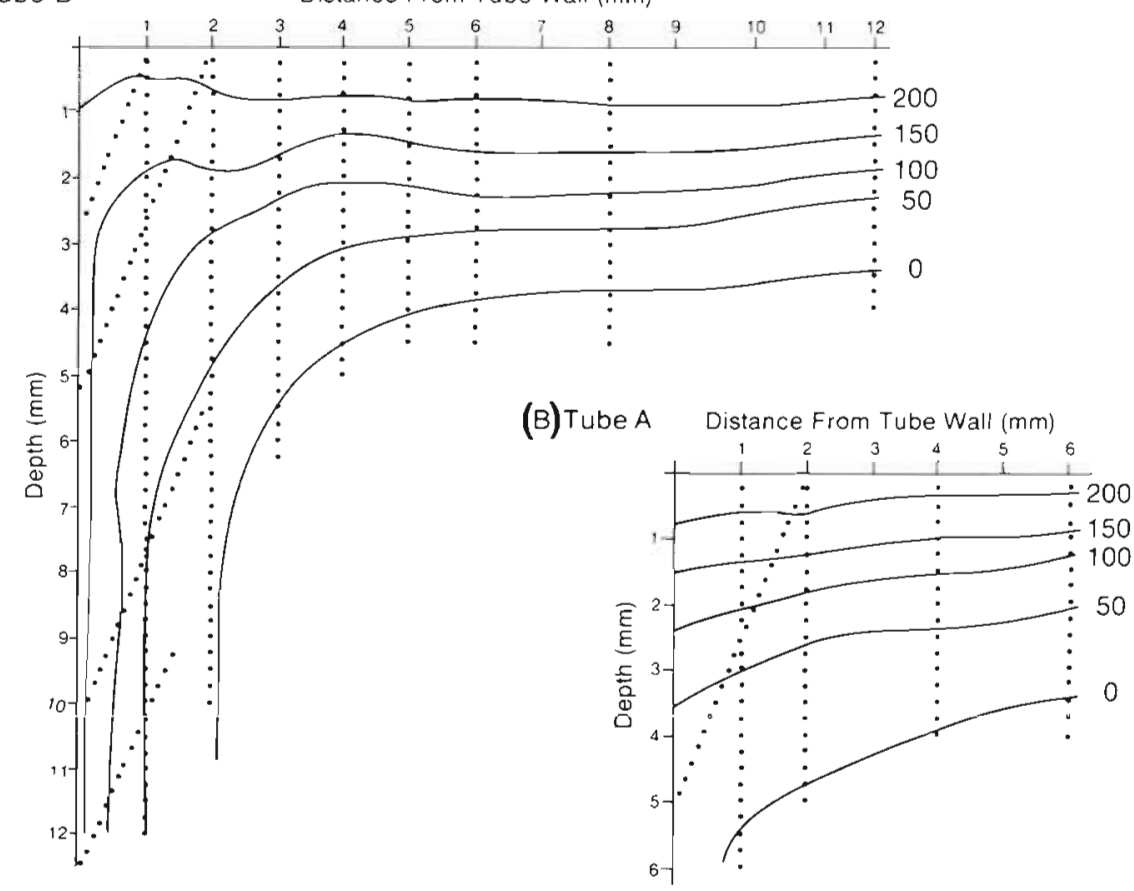

Fig. 4. Oxygen profiles around (A) irrigated and (B) unirrigated tubes after $1 \mathrm{~d}$ of irrigation. Contours in $u \mathrm{M}$. Dots indicate sample locations

\section{Distance From Tube Wall ( $\mathrm{mm}$ )}

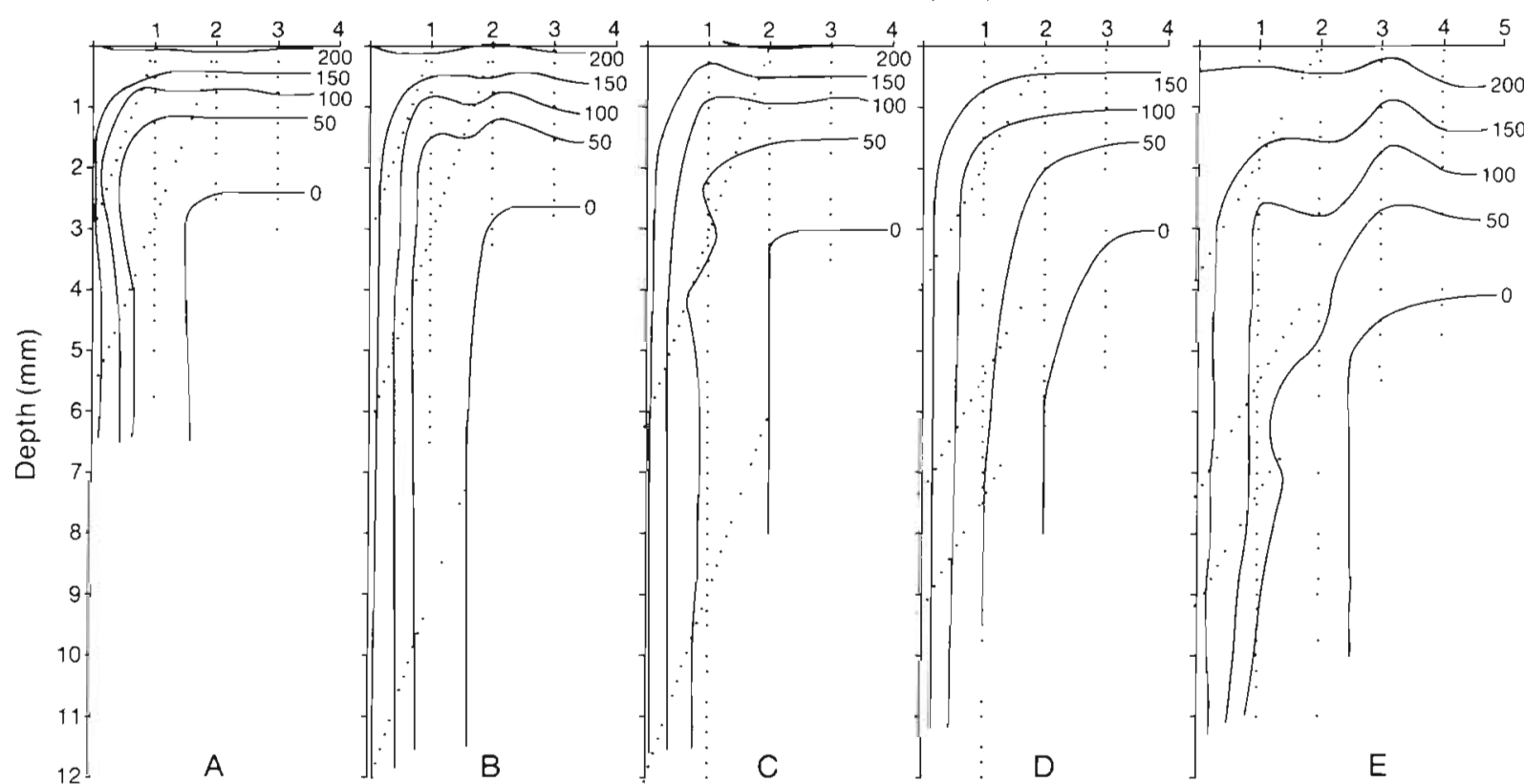

Fig. 5. Formation of oxygen gradient around newly irrigated tube (Tube A). Contours are $\mu M \mathrm{O}_{2}$. (A) $1 \mathrm{~h}$ after irrigation was started; (B) after $2.5 \mathrm{~h}$; (C) after $4.5 \mathrm{~h}$; (D) after $6.5 \mathrm{~h}_{i}$ (E) after $10 \mathrm{~h}$. Dots indicate sample locations

was common in the surface layer as before (Fig. 7). Kuma sp. was present in the surface layer and just below, but was not particularly attracted to the irrigated tube. Solenofilomorpha cf. funilis and Parahaploposthia thiophilus were present in the subsurface, reduced-gray sediment. Gray sediment nearest the irrigated tube (GRA 2, Fig. 7), however, contained more individuals of all subsurface species than did the gray sediment nearest the unirrigated tube (GRA 3 , Fig. 7). Few individuals were found adjacent to the unirrigated tube.

In April, the color change at the chemocline was 


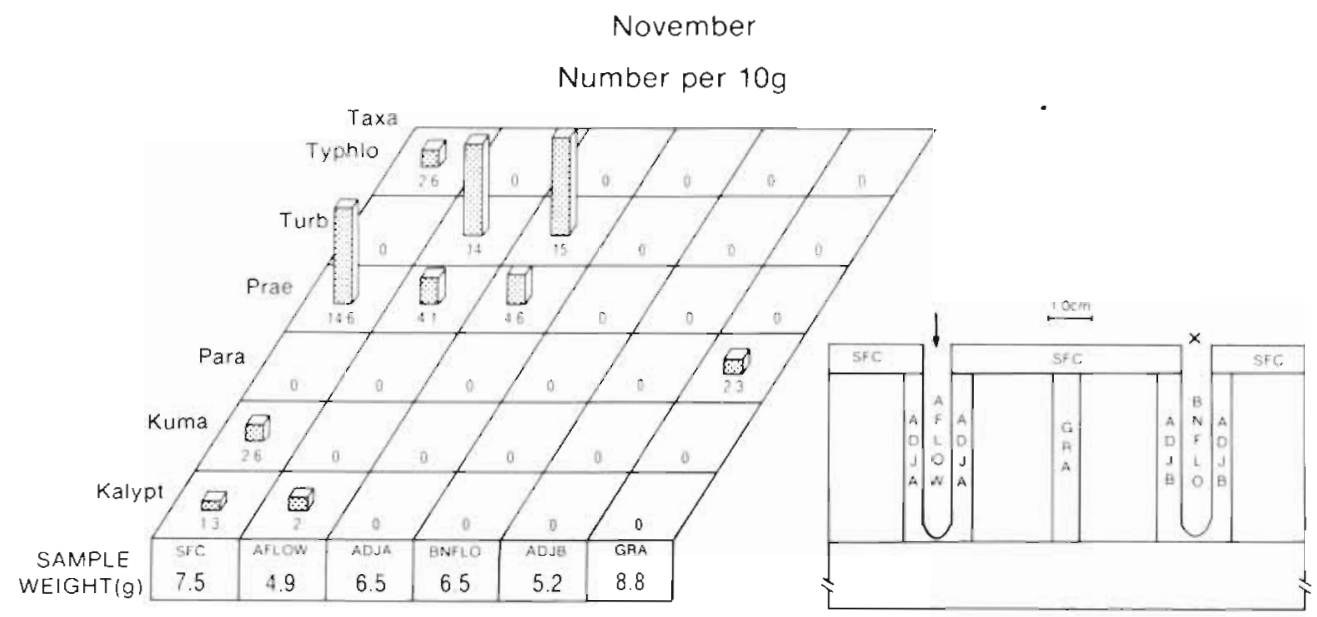

Fig. 6. Meiofaunal distributions in aquaria after $24 \mathrm{~h}$ irrigation of Tube A, Nov 1984 . Taxonomic abbreviations and sample definitions listed in Table 1 . Arrow: irrigated tube; $x$ : unirrigated tube

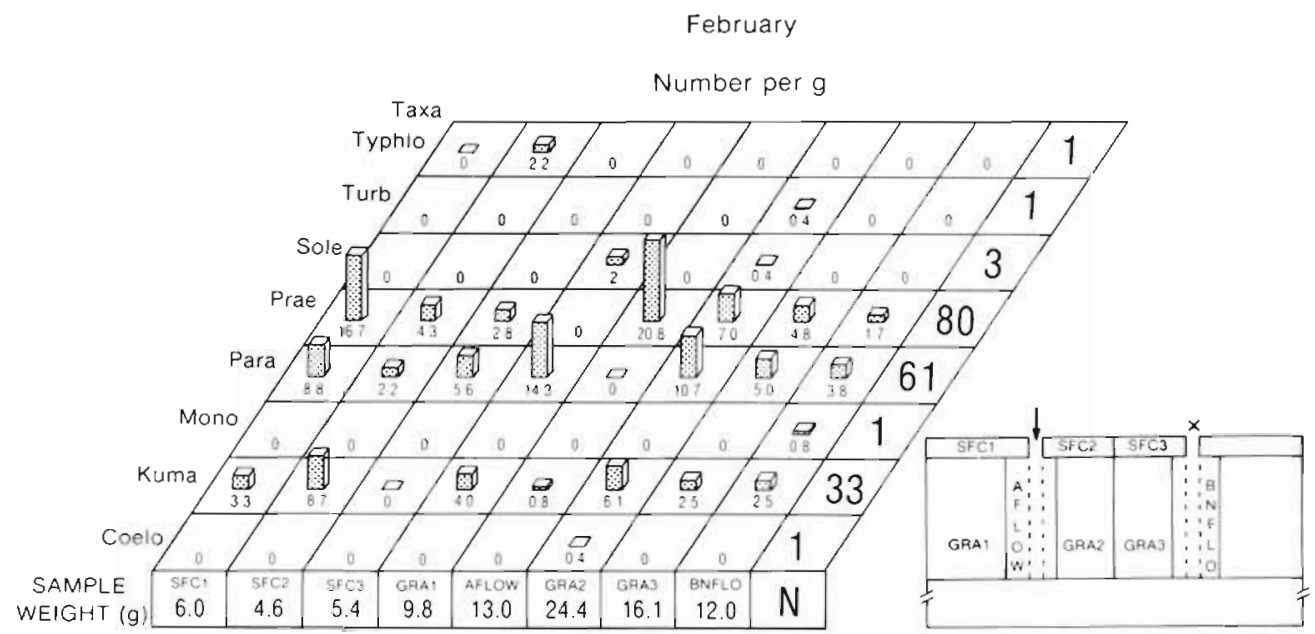

Fig. 7. Meiofaunal distributions in aquaria after $6 \mathrm{~d}$ of irrigation of Tube A, Feb 1985. Taxonomic abbreviations and sample definitions listed in Table 1. Arrow: irrigated tube; $\times$ : unirrigated tube. For scale see Fig. 6

more distinct; sulfide was detectable near the unirrigated tube (Fig. 8). Oxygen penetrated $3 \mathrm{~mm}$ outward from the irrigated tube and 3 to $5 \mathrm{~mm}$ down from the surface (Fig. 8). Under these conditions, Kuma sp. dominated the surface layer ( $\mathrm{SFC}$, down to $5 \mathrm{~mm}$ ) (Fig. 9). Portions of the rhabdocoel population and a lone monocelid individual were present in the surface as well. Praeaphanostoma sp. dominated the region around the irrigated tube while Turbanella ocellata remained in the surrounding gray sediment, preferring that portion nearest the irrigated tube. Parahaploposthia thiophilus was most common in deeper sediments away from the tubes, as was the coelogynoporid. The rhabdocoels also occurred below the surface oxic layer, but tended to favor the irrigated tube and regions surrounding it.
In experiments performed during May and June, the microcosms contained noticeably higher concentrations of dissolved sulfide. Sulfide was measured within 0.5 to $1.0 \mathrm{~cm}$ of the surface (Fig. $10 \& 11$ show a schematic view of oxygen and sulfide distributions in the May and June experiments, respectively). Still, this did not deter meiofaunal individuals from inhabiting deeper sediments (Fig. $12 \&$ 13). Parahaploposthia thiophilus, Solenofilomorpha cf. funilis and Myopea sp. had $>60 \%$ of their respective populations within sulfide-rich sediments. In contrast, few individuals of these species were found in the region where oxygen and sulfide were both in low or undetectable concentrations (samples CLIN1 \& CLIN2). This observation also applies to the chemically comparable area of the irrigated tube (sample ADJB in Fig. 12, sample ADJA 


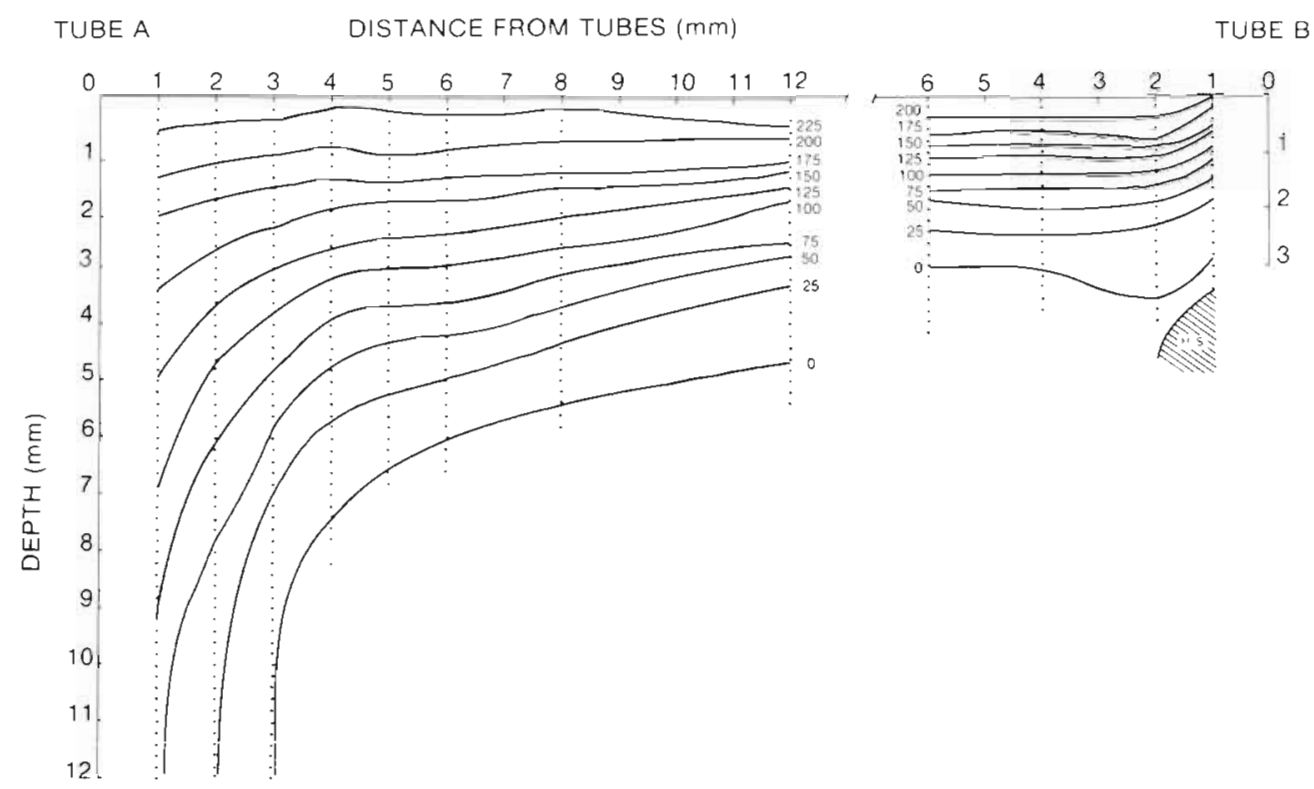

Fig. 8. Sulfide and oxygen distributions in aquarium (Apr 1985) after $8 \mathrm{~d}$ of irrigation of Tube A. Tube B was not irrigated. Contours of $\mathrm{O}_{2}$ in $\mu \mathrm{M} ; \mathrm{H}_{2} \mathrm{~S}$ presence/absence defined as discussed under 'Materials and Methods' Distance between tubes: $80 \mathrm{~mm}$. Dots indicate sample locations

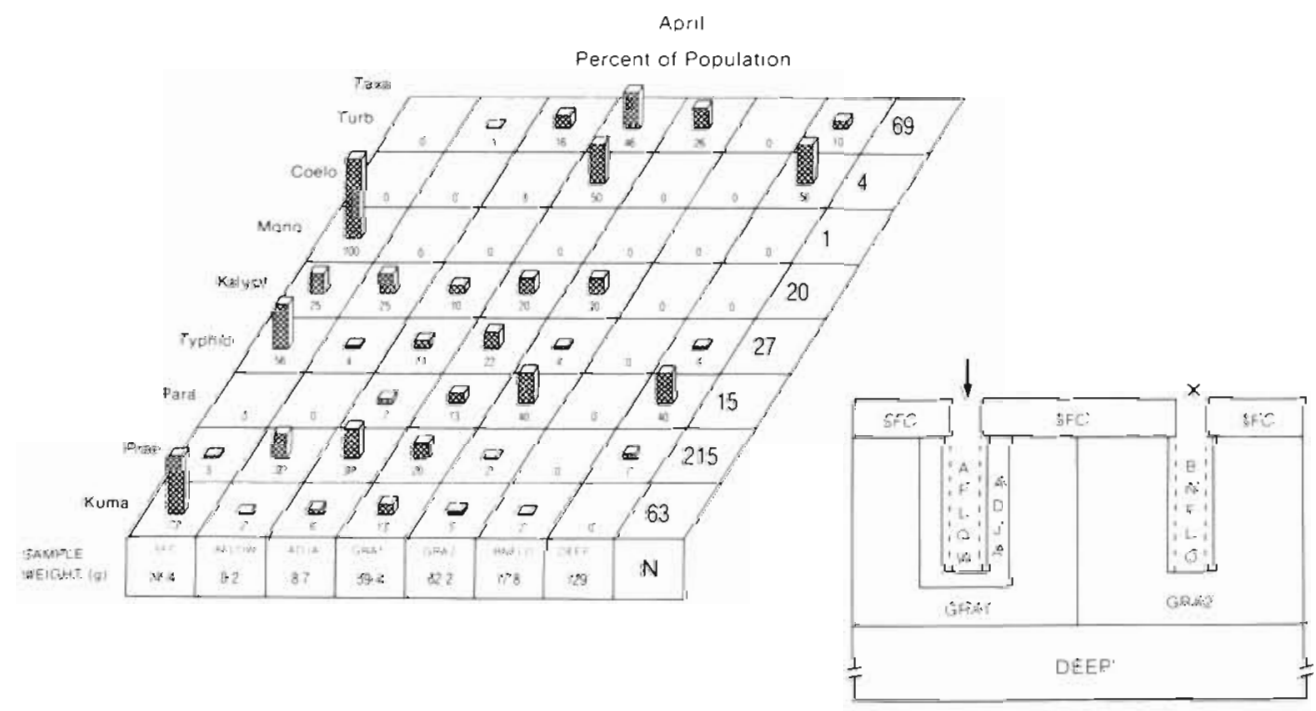

Fig. 9. Meiofaunal distributions in aquarium after $8 \mathrm{~d}$ of irrigation of Tube A (Apr 1985). Tube B was not irrigated. Taxonomic abbreviations and sample definitions listed in Table 1 . Sediment chemistry reported in Fig. 8. Arrow: irrigated tube; $x$. unirrigated tube

in Fig. 13). As before, $P$. thiophilus was abundant in the deeper, most sulfide-rich areas, but was uncommon near the flowing tubes or, in fact, in the gray sediment between the tubes. Myopea sp., the coelogynoporid and $S$. cf. funilis were abundant only in the gray sediment between tubes. Praeaphanostoma sp. and Kuma sp. were most numerous in the microoxic region beneath the surface and the oxic halo around the tubes, but Praeaphanostoma sp. was relatively more abundant around the tubes, Kuma sp. more so in the microoxic region beneath the surface. Turbanella ocellata was most common in the sediment just outside of the oxic halo around the irrigated tube and the chemically comparable region beneath the surface. Unlike Kuma sp. and Praeaphanostoma sp., T. ocellata was rarely found at the surface. Few individuals of any species 


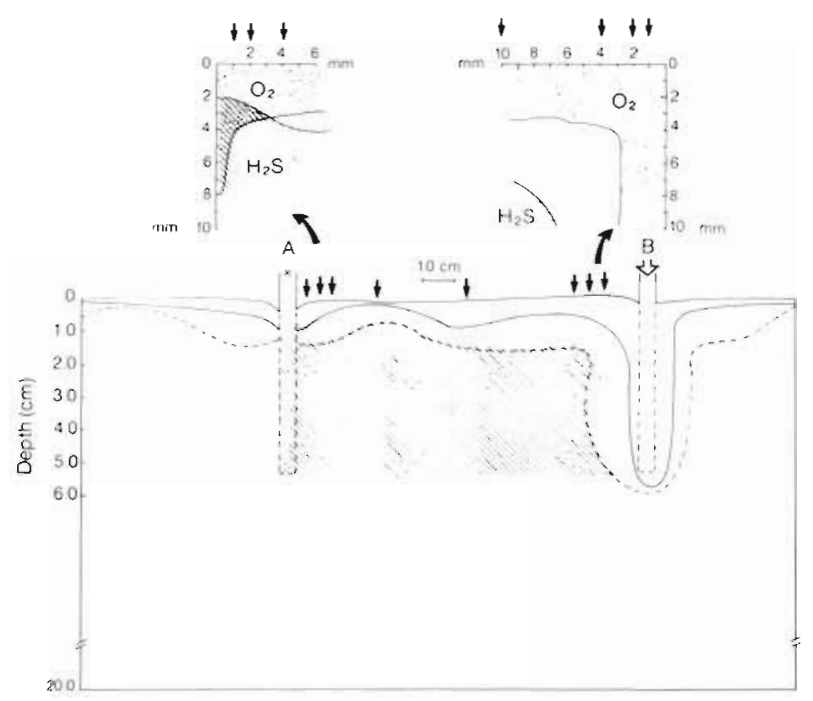

Fig. 10. Sulfide and oxygen distributions in aquarium (May 1985 ) after $9 \mathrm{~d}$ of irrigation of Tube B. Tube A was not irrigated. Solid lines bracket yellow-brown sediment layers. Gray sediments separated by dashed line: light gray regions nearest to yellow sediment, and deeper, darker zones. Sediments with measurable (as defined in the text) sulfide hatched. Oxic sediments stippled. Arrows: positions of chemical profiles; arrow at tube entrance: irrigated tube; $x$ : unirrigated tube. Corresponding meiofaunal distributions shown in Fig. 12

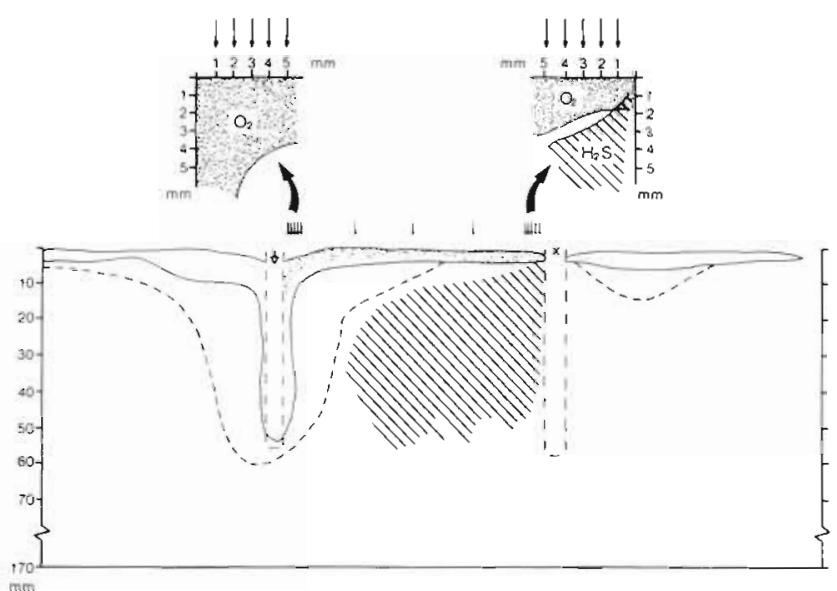

Fig. 11. Sulfide and oxygen distributions in aquarium (Jun 1985) after $9 \mathrm{~d}$ of irrigation of Tube A. Solid lines bracket yellow-brown sediment layers. Gray sediments separated by dashed line indicating light gray regions nearest to yellow sediment, and deeper, darker zones. Oxic sediments, as measured by microelectrode, stippled; sediments with measurable (as defined in text) sulfide by microelectrode hatched. Arrows: positions of chemical profiles. Corresponding meiofaunal distributions shown in Fig. 13. Arrow at tube entrance: irrigated tube; $x$ : unirrigated tube

were collected near the unirrigated tube in either experiment. Moreover, in both experiments, the gray sediment nearer the irrigated tube was inhabited by more individuals than that nearer the unirrigated tube.

\section{DISCUSSION}

\section{Field distributions}

Unlike many sites previously studied, the Corpus Christi Bay site had surprisingly few surface biota and most of these could be found 3 to $20 \mathrm{~mm}$ below the surface. The upper $3 \mathrm{~mm}$ were nearly uninhabited. Reise (1983) and Fitzhugh \& Fleeger (1985) found somewhat similar distributions, and Watzin (1985) rarely observed surface biota right at the surface. Most taxa classically considered to be surface oxybiota had population maxima close to, in or just below the oxidized/reduced boundary at about $5 \mathrm{~mm}$ depth. By contrast, taxa living predominantly below the upper $1 \mathrm{~cm}$ were extremely abundant.

The vertical distribution of taxa was typical: a 'surface' oxybiota and a subsurface so-called thiobiota. The latter could be subdivided as previously suggested by Boaden (1977), Maguire (1977) and Powell et al. (1979) into taxa living near the oxidized/reduced boundary and those living over a greater depth range with substantial abundances to at least $10 \mathrm{~cm}$ depth. Moreover, most taxa showed strong preferences for burrows and tubes as described by Reise (1981a,b). Nevertheless, the individuals found close to burrows/ tubes represented a small fraction of the total biota present (as previously alluded to by Boaden 1980) because the tube microhabitat contributed a relatively small amount of the total sediment volume at depth at the site. Consequently, although many species congregated (higher number $\mathrm{cm}^{-3}$ ) near tubes, a large proportion of the total number of individuals of these species was found elsewhere. In fact, no more of the taxa enumerated in Table 2 were collected in samples in which tubes/burrows were present than in samples without these structures. Spearman's rank analyses showed few significant correlations among species and almost none between any species and tubes/burrows (Table 6). Thistle \& Sherman (1985) obtained a similar result. Consequently, the abundance of individuals around tubes/burrows explained surprisingly little of the overall distributional pattern.

Taxon-by-taxon comparisons frequently showed substantial differences in fine-scale distribution vis-àvis tubes/burrows; some taxa were most common around tubes, others around burrows, for example. From sampling period to sampling period these preferences changed. For example, Solenofilomorpha $\mathrm{cf}$. funilis was most common around Diopatra cuprea tubes on one occasion (Table 4), but less common on the other (Table 5). The burrow wall yielded more individuals than sediment near the burrow in one case (Table 4); the pattern was reversed in the other (Table 5). Reise (1984) described similar phenomena. 

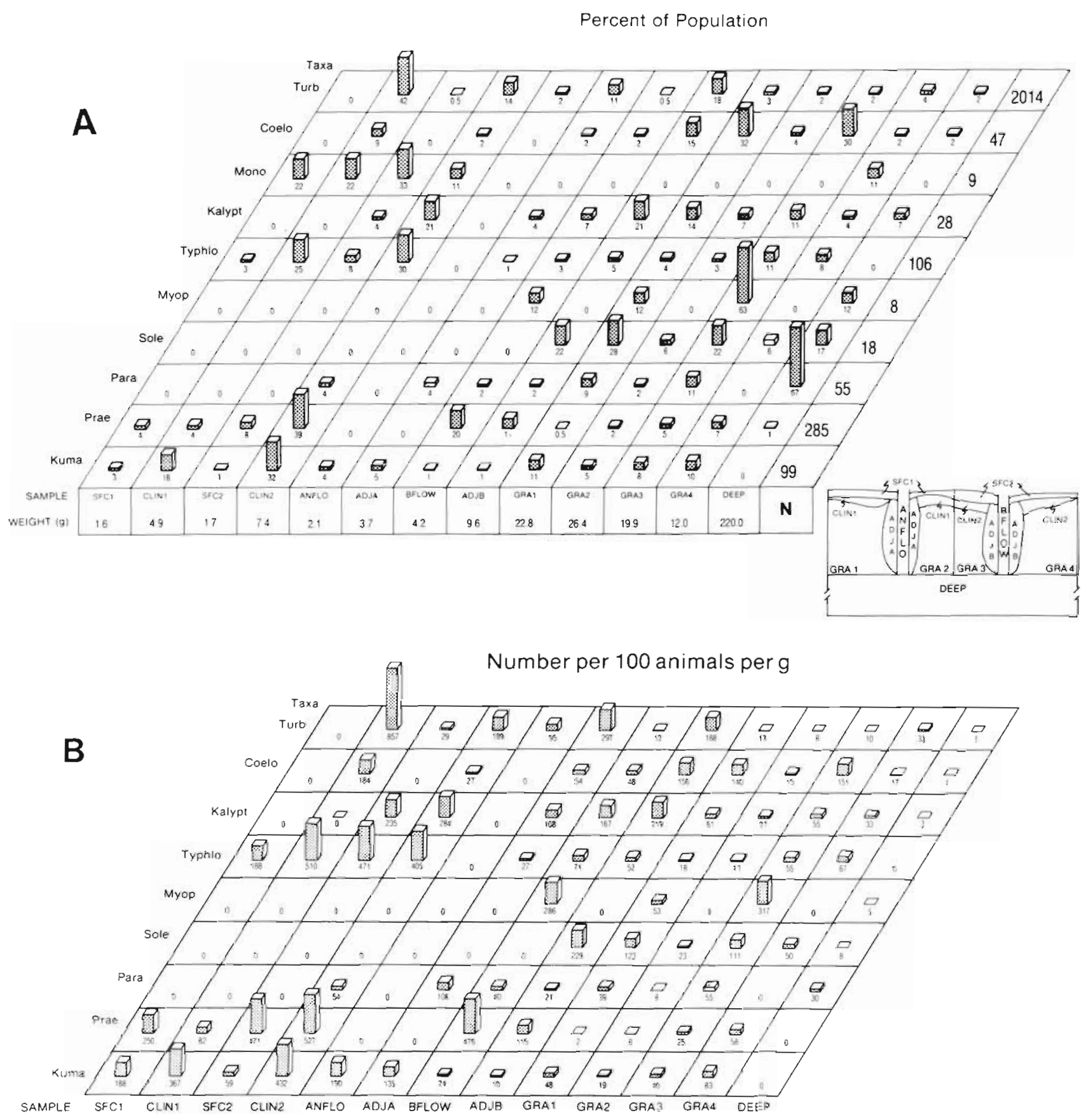

Fig. 12. Meiofaunal distributions (May 1985). (A) Data expressed as percent of population in each sample for each taxon; taxonomic abbreviations and location codes listed in Table 1; chemical data in Fig. 10 \& 5E. (B) Same distribution but graphed as number per 100 individuals per $\mathrm{g}$

Moreover, a comparison of the distribution of individuals among cores at any one sampling yielded few significant correlations (e.g. Table 6) even though one might expect correlations if a single dominant factor was involved in determining the distribution of individuals. Those correlations that were significant were rarely significant in 2 consecutive sampling periods. Consequently, beyond the few broad trends already described, little consistency in spatial distribution was observed.

We considered the possibility that the data only yielded a few broad trends because either the sampling scheme was poorly designed for the actual microhabitats present (perhaps we did not understand what the true microhabitats really were), or that disequilibria in sediment chemistry produced continually 


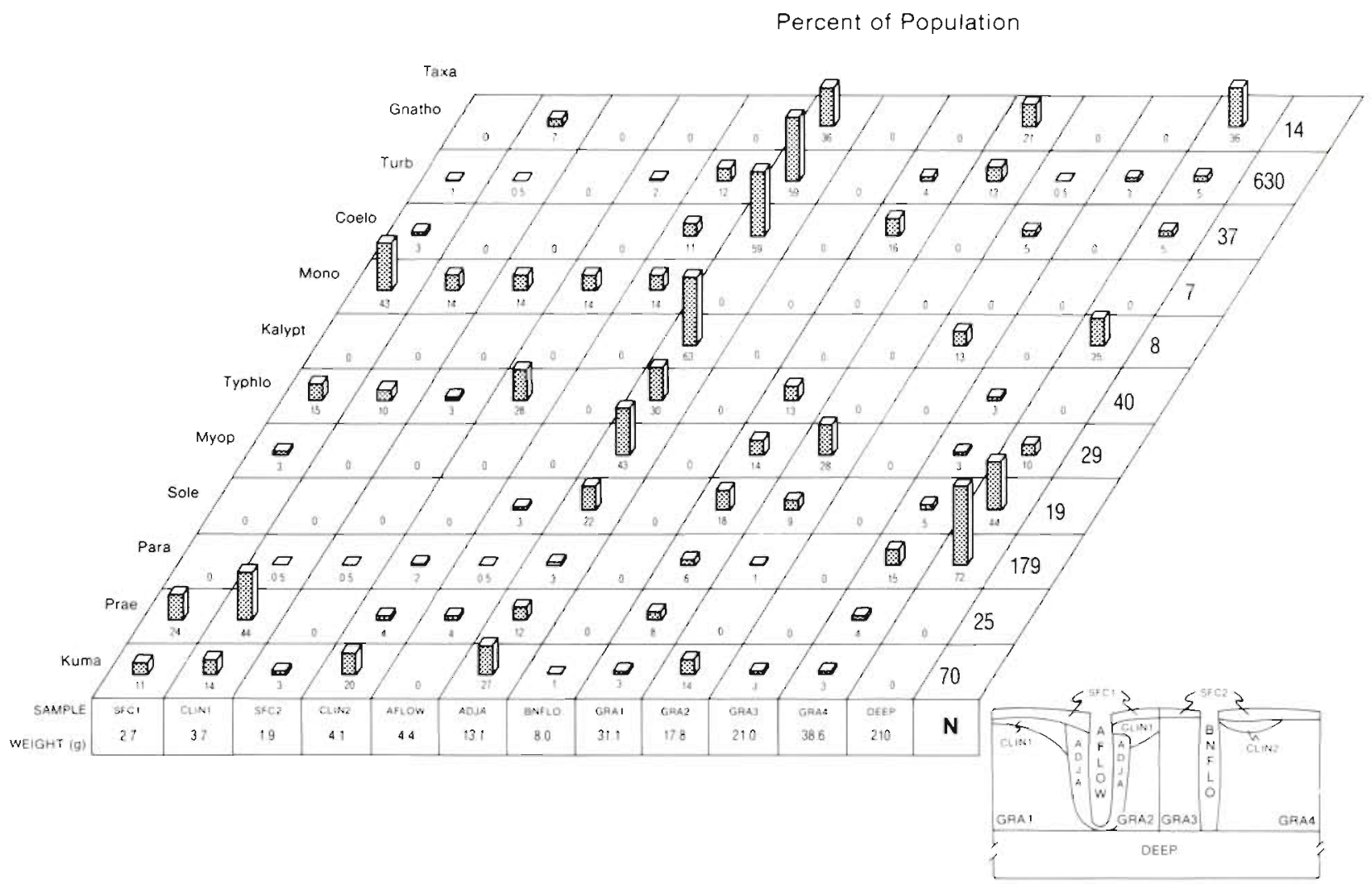

Fig. 13. Meiofaunal distributions (Jun 1985). Data expressed as percent of population in each sample for each taxon. Taxonomic abbreviations and location codes listed in Table 1 Chemical data in Fig. 11

changing spatial distributions and microhabitat structures. An anomalous subsurface oxidized patch contained relatively many individuals typically found associated with tubes, for example (Table 5). Sediment chemistry changes on hourly time scales as well as seasonally, and most burrows/tubes at our site were short-lived structures inhabited, perhaps, for only a day or so (e.g. Ott \& Machan 1971, Powell 1977. Gnaiger et al. 1978). Consequently, many individuals at any given time might be in transit between preferred habitats or be present in suboptimal habitats that, at some earlier time, had been optimal. Thus, we chose to investigate distributional patterns further by observing species behavior and fine-scale distribution under equilibrium conditions in laboratory microcosms. Bark \& Goodfellow (1985) used a similar approach.

\section{Laboratory microcosm experiments}

A relatively constant pattern of species distribution was observed among the experiments with sufficient similarity with field distributions to indicate that the laboratory microcosms mimicked field conditions reasonably accurately (see also Bark \& Goodfellow
1985). Surface taxa in the field (Group III, Fig. 3) were found at the surface of the aquaria. Taxa restricted to the upper part of the subsurface (e.g. Kuma sp. in Group I, Fig. 3) were similarly distributed in the aquaria. Taxa found predominantly around tubes/ burrows in the field (Table 4 \& 5) - such as Turbanella ocellata and Praeaphanostoma sp. - congregated near the artificial tubes in the aquaria. The one taxon found frequently in the reduced sediment between tubes/ burrows in the field, Parahaploposthia thiophilus, was similarly distributed in the aquaria. Consequently, fine-scale distributions not easily studied in the field could be studied successfully in the microcosms.

A continuum of microhabitats was present vertically and horizontally in the aquaria. Above the zero-oxygen line were 3 habitats, the surface proper inhabited by monocelids (and no doubt by the macrostomids and dalyellioids, had they been present) with a few Kuma sp. and Praeaphanostoma sp., an upper chemocline fauna (also observed by Jensen 1983) characterized by Kuma sp. and some Turbanella ocellata, and a fauna inhabiting the oxic halo of the irrigated tube, typified by Praeaphanostoma sp. Except for the surface proper, $\left[\mathrm{O}_{2}\right]$ was much less than $50 \mu \mathrm{M}(\ll 20 \%$ saturation) where these species chose to live.

Below the zero-oxygen line, uniformity of distribu- 
Table 6. Examples of Spearman's rank analyses for 3 of the data sets reported in Table 2

\begin{tabular}{|c|c|c|c|c|c|c|c|c|c|c|c|c|}
\hline & Turb & Kalypt & Typhlo & Macro & Myop & Sole & Prae & Para & Kuma & Gnatho & Coelo & Mono \\
\hline \multicolumn{13}{|c|}{ February $(n=20)$} \\
\hline Poly & -.27 & -.06 & .04 & -.12 & -.11 & .31 & -.02 & -17 & .02 & & & \\
\hline Kuma & -.00 & -.37 & $-.39^{\prime}$ & 12 & .27 & -.11 & -.03 & .23 & & & & \\
\hline Para & .18 & $.41 \cdots$ & .03 & .28 & $39 \cdots$ & .16 & $.52 \cdots$ & & & & & \\
\hline Prae & $.49^{\cdots} \cdot$ & -.03 & .28 & .34 & 31 & -.06 & & & & & & \\
\hline Sole & .19 & -.12 & .03 & -.28 & -.18 & & & & & & & \\
\hline Myop & -.05 & -.17 & .08 & .08 & & & & & & & & \\
\hline Macro & -.01 & .56 & $.47^{\cdots}$ & & & & & & & & & \\
\hline Typhlo & $.39^{*}$ & -.02 & & & & & & & & & & \\
\hline Kalypt & .00 & & & & & & & & & & & \\
\hline \multicolumn{13}{|c|}{ October $(n=20)$} \\
\hline Poly & $.37^{\circ}$ & & & & .00 & .18 & .01 & .22 & .22 & $.60^{\cdots} \cdots$ & .27 & -.31 \\
\hline Mono & .08 & & & & .22 & 30 & .21 & .09 & .07 & .25 & -.13 & \\
\hline Coelo & $.54^{\cdots} \cdots$ & & & & .08 & $.39^{\circ}$ & 12 & $37^{\circ}$ & -.18 & $.32^{\circ}$ & & \\
\hline Gnatho & $.48^{\cdots} \cdot$ & & & & .07 & $.63 \cdots$ & .21 & .14 & .07 & & & \\
\hline Kuma & $-.37^{\circ}$ & & & & $.52 \cdots$ & .27 & .01 & $.51 \cdots$ & & & & \\
\hline Para & .02 & & & & $.57^{\cdots} \cdots$ & $.32^{\circ}$ & $.49^{\circ}$ & & & & & \\
\hline Prae & .07 & & & & $.31^{\circ}$ & .25 & & & & & & \\
\hline Sole & .22 & & & & $44^{\cdots}$ & & & & & & & \\
\hline Myop & -.14 & & & & & & & & & & & \\
\hline \multicolumn{13}{|c|}{ April $(n=17)$} \\
\hline Poly & .18 & .09 & $.52 \cdots$ & & .03 & .10 & .28 & 17 & -.08 & & 18 & \\
\hline Coelo & $.37^{\circ}$ & $.39^{\circ}$ & $.53 \cdots$ & & $.43^{\cdots}$ & .07 & -.07 & -.20 & .06 & & & \\
\hline Kuma & -.20 & -.10 & .02 & & $49^{\cdots} \cdots$ & 17 & -.24 & $39^{\circ}$ & & & & \\
\hline Para & $.73 \cdots \cdots$ & -.06 & .13 & & .31 & .16 & .13 & & & & & \\
\hline Prae & .16 & 17 & .28 & & 19 & .24 & & & & & & \\
\hline Sole & $.33^{\circ}$ & -.11 & -.13 & & .06 & & & & & & & \\
\hline Myop & -.01 & -.11 & $-.35^{\circ}$ & & & & & & & & & \\
\hline Typhlo & .26 & $.66^{\cdots} \cdots$ & & & & & & & & & & \\
\hline Kalypt & 19 & & & & & & & & & & & \\
\hline
\end{tabular}

tion was not apparent either. Parahaploposthia thiophilus consistently preferred sediments farthest from the artificial tubes or the surface, typically inhabiting sediments below tube depth. Within the layer of sediment occupied by tubes, a horizontal gradient of distribution existed: Turbanella ocellata frequented the sediment just outside the oxic halo around tubes; Myopea sp. and Solenofilomorpha cf. funilis preferred the gray sediment between tubes.

Overall, the distributions of taxa living below the zero-oxygen line followed a presumed sulfide gradient: Parahaploposthia thiophilus preferred the highest-sulfide zone; Turbanella ocellata, the low-to-zero sulfide, zero $\mathrm{O}_{2}$ habitat; and the solenofilomorphids an intermediate condition. Overall, most subsurface taxa could be found relatively near the irrigated tube. The sediment between the unirrigated and irrigated tube was divided in half. More individuals occupied the half nearest the irrigated tube (Wilcoxon signed-ranks text, $\mathrm{p}<0.05$ ). Essentially all species preferentially occupied the half nearest the irrigated tube (sign test, $\mathrm{p}=0.001)$. Only $P$. thiophilus was a numerically important exception in any experiment (e.g. Fig. 6).
Consequently, the field observation that most taxa congregate near tubes was duplicated in the laboratory.

Surprisingly, even though the environment of the irrigated tube was attractive to most subsurface taxa, only 1 species, Praeaphanostoma sp., was regularly observed in the oxic halo around it. The others preferred habitats outside the zero-oxygen line. All taxa preferred the irrigated tube relative to the unirrigated tube. Hence, tube irrigation and the chemical gradient produced by it, not the tube structure itself, was responsible for this attraction, and this chemical effect was perceived much beyond the zero-oxygen line demarcating the visually apparent oxic halo around the tube (see also Aller's 1984 model).

The data confirm the observations of Reise (1981a, 1984) that many microhabitats exist below the surface layer of sandy marine sediments. Factors responsible for the observed distributions must be the consequences of tube/burrow irrigation. Meiofaunal species exhibit a range of tolerances to oxygen and sulfide (e.g. Lasserre \& Renaud-Mornant 1973, Warwick \& Price 1979). The observed distributions agree precisely 
with those inferred by Powell et al. $(1979,1980)$ and Fox \& Powell $(1986 a, b)$ from studies on sulfide toxicity and the role of oxygen in metabolism. Oxybiotic species living above the zero-oxygen line, such as Kuma sp., were sensitive to sulfide; aerobic metabolism was sulfide-sensitive and ATP levels declined under sulfide exposure, for example. In contrast, thiobiotic species had a sulfide-insensitive aerobic metabolism. Even the differences in microhabitat of Solenofilomorpha cf. funilis and Parahaploposthia thiophilus could be predicted from the end products of sulfide detoxification and the effect of oxygen and sulfide on metabolism. $P$. thiophilus utilized oxygen to a much lower extent in every case. Thus, metabolic capabilities suggest that the species are moderately restricted to a subset of available microhabitats determined by $\mathrm{O}_{2}$ and sulfide concentrations.

Chemistry is not a complete explanation, however. Some microhabitats were similar, if not identical, chemically, yet species composition was dissimilar. Kuma sp. preferred the microoxic habitat just below the surface, for example, whereas Praeaphanostoma sp. preferred the walls of irrigated tubes; yet oxygen and sulfide concentrations were very similar in both areas. An additional explanation might be food availability. The chemical gradients establish bacterial gradients based on available terminal electron acceptors and electron donors (e.g. Goldhaber \& Kaplan 1974, Jørgensen \& Fenchel 1974, Novitsky \& Kepkay 1981). Differences in the composition of organic matter, between tube walls and the organic detritus in surrounding sediments for example, may also produce differential bacterial distributions (consider data reviewed by Laanbroek \& Veldkamp 1982, for instance). Some meiofaunal species do exhibit preferences for certain species of bacteria (e.g. Gray 1966, Gray \& Johnson 1970), and differential food requirements have been suggested as a cause of microdistributional patterns (Carman \& Thistle 1985). Consequently, differences in food quality and quantity may be important.

Predation or disturbance did not seem to affect the vertical distributions, except perhaps on evolutionary time scales. Our laboratory results, free from such effects, coincided well with field observations. Competition for food, however, may be important. Powell \& Bright (1981) suggested that the sulfide system might be food-limited. In our study, few numerically dominant species had substantially overlapping distributions (e.g. Tables 7 \& 8). Optimal habitat, as deduced from population maxima, usually differed. Nearly all exceptions involved taxa which could be expected to have different food requirements (e.g. the coelogynoporid proseriate $v s$ the solenofilomorphid acoel). Among the acoels and the gastrotrich Turbanella
Table 7. Pairwise Kolmogorov-Sminov 2-sample 2-sided tests for distributions from Fig. 12

\begin{tabular}{|lcccccc|}
\hline & Kuma & Prae & Para & Sole & Mono & Coelo \\
\hline Turb & sig & sig & sig & sig & - & sig \\
Coelo & sig & sig & sig & - & sig & \\
Mono & sig & sig & sig & sig & & \\
Sole & sig & sig & sig & & & \\
Para & sig & sig & & & & \\
Prae & sig & & & & & \\
Sig: $\mathrm{p} \leq 0.05 ;-: \mathrm{p}>0.05$ & & & & \\
\hline
\end{tabular}

Table 8. Pairwise Kolmogorov-Smirnov 2-sample 2-sided tests for distributions from Fig. 13

\begin{tabular}{|lcccccccc|}
\hline \multicolumn{1}{r}{ Kuma } & Prae & Para & \multicolumn{3}{c|}{ Sole } & Myop Mono Coelo Turb \\
\hline Gnatho & sig & sig & sig & - & - & sig & sig & - \\
Turb & sig & sig & sig & sig & sig & sig & - & \\
Coelo & sig & sig & sig & sig & - & sig & \\
Mono & - & - & sig & sig & sig & & \\
Myop & sig & sig & sig & - & & & \\
Sole & sig & sig & sig & & & & \\
Para & sig & sig & & & & & \\
Prae & sig & & & & & \\
Sig: $\mathrm{p} \leq 0.05 ;-: \mathrm{p}>0.05$ & & & & \\
\hline
\end{tabular}

ocellata, which may have similar food requirements and which dominated the assemblages, only the solenofilomorphids Myopea sp. and Solenofilomorpha cf. funilis had broadly overlapping distributions.

Summer and winter experiments, although similar overall, differed in some respects. Sulfide concentration was low in the winter throughout the aquarium, but high in summer, particularly below the depth of the irrigated tube's influence and near the unirrigated tube. The range of the coelogynoporid proseriate was restricted in summer to a smaller area where sulfide concentration was low, whereas in winter, the same species was more widely distributed in the deeper sediments. Parahaploposthia thiophilus was more widely distributed in the winter as well, possibly because its optimal habitat did not exist at that time. We suggest that much of the seasonally varying distributional patterns described by Reise (1984) may be due to seasonal changes in sediment chemistry expanding and contracting, creating and removing, optimal microhabitats. Furthermore, changes even on a daily basis should be of sufficient magnitude to produce continually changing species distributional patterns as a portion of the individuals are forced, in effect, to relocate optimal microhabitat.

Surprisingly, most oxybiota were apparently microoxyphilic (see also Jensen 1983, Bark \& Goodfellow 
1985); we prefer the term microoxyphilic to dysaerobic (Rhoads \& Morse 1971) because the latter is now frequently used to denote benthic communities, and their taxa, found where near-bottom oxygen concentrations are continuously low (e.g. Savrda et al. 1984, Thompson et al. 1985). Only a monocelid proseriate, the macrostomids and the dalyellioids among the species living above the zero-oxygen line preferred $\mathrm{O}_{2} \geq 50 \%$ saturation. Among the microoxyphiles, some clearly preferred tubes rather than other microoxyphilic microhabitats. Thus, Reise \& Ax's (1979) contention that subsurface species are oxybiota living around tubes/ burrows is, in part, correct. We emphasize that the term microoxyphilic connotes neither a physiological nor metabolic requirement for microoxic habitat, but simply an ecological fact. Some taxa may be euryoxic whereas others may be obligately microoxyphilic.

One frequently recognizes surface taxa by their greater mobility. Species of Macrostomum, for example, normally swim in an extraction dish. Surprisingly, many of the microoxyphiles exhibited similar behavior even though they rarely live at the surface. Kuma sp., for example, swam frequently. Addition of sulfide eliminated swimming completely (Fox \& Powell, 1986b). One explanation for the occasional Kuma sp. observed in sulfidic sediments in the microcosms (e.g. Fig. 13) may be that sulfide-induced immobility trapped them there as sediment was added initially. They were unable to migrate toward the surface. Many fewer Kuma sp. were found below the zero-oxygen line in winter when mobility might be much improved because sulfide was present in only trace quantities. In contrast, most fauna normally living below the zerooxygen line were infrequent swimmers at best.

All the classic thiobiotic species (sensu Crezee 1976, for example) lived below the zero-oxygen line. None were obligate anaerobes as originally proposed by Boaden (1975). Fox \& Powell (1986b) demonstrated that all were capable of aerobic metabolism. Certainly all of them must live below their critical oxygen level $\left(\mathrm{P}_{c}\right.$ of Pörtner et al. 1985), however, so that much or all of their daily metabolism must be anaerobic. Even among the classic thiobiota, in spite of a clear preference for microhabitats with no measurable oxygen, all but one taxon demonstrated a clear preference for sediments near the irrigated tube. Consequently, distributional patterns vis-à-vis tubes/burrows cannot be used to infer oxygen/sulfide requirements for interstitial species. The chemical gradients present around these structures are sufficient to encompass an array of microhabitats of widely divergent chemistries, which nevertheless would produce a tube/burrow-oriented distributional pattern.

We rarely observed individuals of thiobiotic species above the zero-oxygen line. Nevertheless, a capacity for aerobic metabolism suggests some exposure to molecular oxygen and anabolic requirements suggest that these taxa probably do require some oxygen (Powell \& Bright 1981, Bark \& Goodfellow 1985). Accordingly, we emphasize that our previous use of the term 'microoxyphilic' for species above the zerooxygen line does not imply that thiobiota do not require oxygen. Insufficient data are available to judge the verity of this claim. We use the term simply to distinguish taxa inhabiting low-oxygen, sulfide-free habitats from taxa inhabiting sulfidic habitats. However, we do suggest that most of daily metabolism in thiobiotic species must take place in an oxygen-free environment so that oxygen, if required, must be obtained by migratory behavior plus an oxygen storage system. Furthermore, such behavior can only involve a very small percentage of the population at any time.

There is an unfortunate tendency to call any subsurface orientation to tubes/burrows commensalism. In all likelihood, these species interact with structure in a somewhat analogous way to above-ground species living on algae (Coull \& Wells 1983) or Diopatra tubes (Bell 1985) in that specific physical or chemical conditions associated with structures are attractive, rather than any taxonomic specificity or preference per se. Even Praeaphanostoma sp. was not restricted to any one or even several related tube types. Any locale having the desired physical-chemical milieu was attractive. Certainly, neither an animal nor the mucopolysaccharide-protein lining produced by it was required. Artificial tubes of glass and cellulose served just as well. In fact, in the microcosms, the unirrigated tube was never attractive. Hence, the physical-chemical environment produced by irrigation was all-important. Commensalism is a poor term for this association.

\section{CONCLUSIONS}

Consideration of the sulfide system and thiobios has centered on the role played by oxygen and sulfide ecologically and metabolically. The data presented here corroborate and expand the view that subsurface meiofauna are distributed in many microhabitats and that these microhabitats are determined for the most part by macrofaunal interactions with sediment chemistry. Moreover, nearly all, but not all, subsurface taxa are consistently attracted to burrows/tubes. Some results were surprising. Most oxybiotic taxa were microoxyphilic, living beneath the surface few millimeters of sediment. All of the classic thiobiotic species lived below the zero-oxygen line, yet most demonstrated a clear preference for sediments near the irri- 
gated tube. The size of some optimal habitats was surprisingly small, frequently no more than 1 to $2 \mathrm{~mm}$ thick. This is no more than 2 to 3 times the animal's length. Hence, microhabitat exists on nearly the same scale as the animal's size. Lateral movement of no more than 2 to 3 body lengths may result in movement from optimal to suboptimal environments, some of which might be beyond the adaptive range of the species. The relatively poor resolution of distributional patterns observed in field data, as discussed earlier, probably reflects the difficulty of sampling on this scale without careful prior chemical measurements; as well as the continually changing chemical conditions normally observed in marine sands which produce disequilibria between microhabitat structure and species distribution.

Powell et al. (1983) suggested that thiobios were organisms living in the chemocline. Our data show a continuum of microhabitats throughout the oxygensulfide gradient of marine sands. Some taxa living near the high-oxygen end of the gradient conform to Reise \& Ax's (1979) view of subsurface Metazoa. Others at the high-sulfide end come close to Boaden's (1975) view of thiobiota. Even the 3-layer models comprising surface, chemocline and deeper taxa do not adequately represent this complexity (e.g. Boaden 1977. Maguire 1977. Powell et al. 1979). If it remains useful to differentiate between oxybiota and thiobiota, the chemocline offers a poor line of demarcation. Some obviously oxybiotic taxa live in this gradient.

Powell et al. (1983) suggested that thiobios had an ecologic requirement for sulfide. The presence of sulfide may represent a metabolically important line of demarcation because taxa living in sulfidic microhabitats require an enhanced capacity for sulfide deoxification and marked changes in metabolism. A sulfide-insensitive aerobic metabolism and increased reliance on anaerobic metabolism would be examples (Fox \& Powell 1986b). In this article, we have tacitly taken the zero-oxygen line as the line of demarcation between oxybiota and thiobiota. Somewhere below this line, sulfide concentration rises sufficiently, at least during summer, to require considerable changes in metabolism for metazoan life. In practice, those taxa previously considered to be thiobiota (e.g. Gnathostomulida) live below this line. Additionally, the zerooxygen line conforms to previous data demonstrating an ecologic requirement for sulfide in thiobiotic taxa (Powell et al. 1983) and to historical usage (Boaden 1975, 1977). It fails, however, to categorize a few important taxa, such as Turbanella ocellata, which congregate just at the zero-oxygen line. We also have tacitly assumed that taxa above this line orient along an oxygen gradient and taxa below this line orient along a sulfide gradient. There is, of course, little good evidence in support of this assumption beyond that reported by Powell et al. (1983).

An important, but unanswered question, then, is to what extent the demarcation between thiobiota and oxybiota is biologically important or merely pedagogically useful. Presently available data on ecology and metabolism strongly suggest that many taxa are fundamentally constrained to life in sulfidic sediments because of metabolic adaptations and, perhaps, trophic requirements. We suggest that the adaptive range of suboptimal habitat might prove to be a sensitive indicator of the real biological importance of these constraints. Certainly optimal habitat should frequently be unavailable, because most burrows/tubes are temporary structures, so that life in, or migration through, suboptimal habitat should be a normal occurrence. We suggest that, when optimal habitat disappears - when a burrow is abandoned, for example - thiobiota should preferentially move into suboptimal sulfidic microhabitats; microoxyphilic oxybiotic into more oxygenrich suboptimal habitats; and that this behavior should agree with metabolic constraints on the species. Such behavior would confirm the ecological importance of sulfide, emphasize an important point of demarcation near the zero-oxygen line, and strengthen the view that thiobiota are an ecologically distinctive subset of the meiofauna.

Acknowledgements. We thank C. Fox for help with the field studies and Drs. Julian Smith and William Hummon for assistance with the taxonomy of the turbellarians and gastrotrichs, respectively. M. Cook and F. O'Hara provided crucial help in fabricating the specialized equipment for microelectrode measurements. Critical comments by Dr. S. Bell, Mr. J. Parrack and 2 anonymous reviewers improved the manuscript considerably. We thank R. Covington for typing the manuscript and tables. This study was supported by the National Science Foundation grant no. OCE-8219792 and by the Danish Natural Science Research Council grant no. 11-4973.

\section{LITERATURE CITED}

Aller, R. C. (1984). The importance of relict burrow structures and burrow irrigation in controlling sedimentary solute distributions. Geochim. cosmochim. Acta 48: 1929-1934

Aller, R. C., Yingst, J. Y. (1978). Biogeochemistry of tubedwellings: a study of the sedentary polychaete Amphitrite ornata (Leidy). J. mar. Res. 36: 201-254

Aller, R. C., Yingst, J. Y. (1985). Effects of the marine depositfeeders Heteromastus filiformis (Polychaeta), Macoma balthica (Bivalvia), and Tellina texana (Bivalvia) on averaged sedimentary solute transport, reaction rates, and microbial distributions. J. mar. Res. 43: 615-645

Aller, R. C., Yingst, J. Y., Ullman, W. J. (1983). Comparative biogeochemistry of water in intertidal Onuphus (Polychaeta) and Upogebia (Crustacea) burrows: temporal patterns and causes. J. mar. Res. 41: 571-604

Alongi, D. M. (1985). Microbes, meiofauna, and bacterial productivity on tubes constructed by the polychaete Capitella capitata. Mar. Ecol. Prog. Ser. 23: 207-208 
Baker, B. L., Baker, K. K., Tyler, P. A. (1985). Close interval sampling of migrating Chaoborus larvae across the chemocline of meromictic Lake Fidler, Tasmania. Arch. Hydrobiol. 103: 51-59

Bark, A. W., Goodfellow, J. G. (1985). Studies on ciliated protozoa in eutrophic lakes: 2. Field and laboratory studies on the effects of oxygen and other chemical gradients on ciliate distribution. Hydrobiologia 124: 177-188

Bell, S. S. (1983). An experimental study of the relationship between below-ground structure and meiofaunal taxa. Mar. Biol. 76: 33-39

Bell, S. S. (1985). Habitat complexity of polychaete tube-caps: influence of architecture on dynamics of a meioepibenthic assemblage. J. mar Res. 43: 647-671

Bemer, R. A. (1963). Electrode studies of hydrogen sulfide in marine sediments. Geochim. cosmochim. Acta 27: 563-575

Boaden, P. J. S. (1975). Anaerobiosis, meiofauna and early metazoan evolution. Zool. Ser. 4: 21-24

Boaden, P. J. S. (1977). Thiobiotic facts and fancies (aspects of the distribution and evolution of anaerobic meiofauna). Acad. Wiss. Lit. Mainz Math. Naturwiss. K1. Mikrofauna Meeresbodens 61: 45-63

Boaden, P. J. S. (1980). Meiofaunal thiobios and the Arenicola negation': case not proven. Mar. Biol. 58: 25-29

Boaden, P. J. S., Platt, H. M. (1971). Daily migration patterns in an intertidal meiobenthic community. Thalassia jugosl. 7: $1-12$

Carman, K. R., Thistle, D. (1985). Microbial food partitioning by three species of benthic copepods. Mar. Biol. 88: $143-148$

Coull, B. C., Wells, J. B. J. (1983). Refuges from fish predation: experiments with phytal meiofauna from the New Zealand rocky intertidal. Ecology 64: 1599-1609

Crezee, M. (1976). Solenofilomorphidae (Acoela): major component of a new turbellarian association in the sulfide system. Int. Revue ges. Hydrobiol. 61: 105-129

Defretin, R. (1971). The tubes of polychaete annelids. In: Florkin, M., Stotz, E. H. (ed.) Comprehensive biochemistry, Vol. 26, Pt. C, Extracellular and supporting structures (cont.). Elsevier Publishing Co., Amsterdam, p. 713-747

Famme, P., Knudsen, J. (1985). Anoxic survival, growth and reproduction by the freshwater annelid, Tubifex sp., demonstrated using a new simple anoxic chemostat. Comp. Biochem. Physiol. A Comp. Physiol. 81: 251-253

Farris, R. A., Lindgren, E. W. (1984). A posteriori investigation of spatial arrangements in Gnathostomulida and Copepoda. Int. Revue ges. Hydrobiol. 69: 443-450

Felbeck, H. (1981). Chemoautotrophic potential of the hydrothermal vent tube worm, Riftia pachyptila Jones (Vestimentifera). Science 213: 336-338

Felbeck, H., Childress, J. J., Somero, G. N. (1981). CalvinBenson cycle and sulphide oxidation enzymes in animals from sulphide-rich habitats. Nature, Lond. 293: 291-293

Felbeck, H., Liebezeit, G., Dawson, R., Giere, O. (1983). $\mathrm{CO}_{2}$ fixation in tissues of marine oligochaetes (Phallodrilus leukodermatus and $P$. planus) containing symbiotic chemoautotrophic bacteria. Mar. Biol. 75: 187-191

Fenchel, T. M. (1978). The ecology of micro- and meiobenthos. Ann. Rev. Ecol. Syst. 9: 99-121

Fenchel, T. M., Jørgensen, B. B. (1977). Detritus food chains of aquatic ecosystems: the role of bacteria. Adv. microb. Ecol. 1: 1-58

Fenchel, T. M., RiedI, R. J. (1970). The sulfide system: a new biotic community underneath the oxidized layer of marine sand bottoms. Mar. Biol. 7· 255-268

Fitzhugh, G. R., Fleeger, J. W. (1985). Goby (Pisces: Gobiudae) interactions with meiofauna and small macrofauna. Bull. mar. Sci. 36: 436-444

Fox, C. A., Powell, E. N. (1986a). Meiofauna and the sulfide system: the effects of oxygen and sulfide on the adenylate pool of 3 turbellarians and a gastrotrich. Comp. Biochem. Physiol. A Comp. Physiol. 85: 37-44

Fox, C. A., Powell, E. N. (1986b). Meiofauna and the sulfide system: the effect of oxygen and sulfide on $\mathrm{CO}_{2}$ production by 3 acoel turbellarians. Comp. Biochem. Physiol. (in press)

Gnaiger, E., Gluth, G., Wieser, W. (1978). pH fluctuation in an intertidal beach in Bermuda. Limnol. Oceanogr. 23: 851-857

Goldhaber, M., Kaplan, I. (1974). The sulfur cycle. In: Goldberg, E. (ed.) The sea, Vol. 5, Marine chemistry. Wiley, New York, p. 569-655

Gray, J. S. (1966). The attractive factor in intertidal sands to Protodrilus symbioticus. J. mar. biol. Ass. U.K. 46: 627-645

Gray, J. S., Johnson, R. M. (1970). The bacteria of a sandy beach as an ecological factor affecting the interstitial gastrotrich Turbanella hyalina Schultz. J. exp. mar Biol. Ecol. 4: 119-1.33

Giere, O., Liebezeit, G., Dawson, R. (1982). Habitat conditions and distribution pattern of the gutless oligochaete Phallodrilus leukodermatus. Mar. Ecol. Prog. Ser. 8: 291-299

Jensen, P. (1983). Meiofaunal abundance and vertical zonation in a sublittoral soft bottom with a test of the Haps corer. Mar. Biol. 74: 319-326

Jørgensen, B. B. (1977). The sulfur cycle of a coastal marine sediment (Limfjorden, Denmark). Limnol. Oceanogr. 22: 814-832

Jørgensen, B. B., Fenchel, T. (1974). The sulfur cycle of a marine sediment model system. Mar Biol. 24: 189-201

Jørgensen, B. B., Revsbech, N., Blackburn, T, Cohen, Y. (1979). Diurnal cycle of oxygen and sulfide microgradients and microbial photosynthesis in a cyanobacterial mat sediment. Appl. environ. Microbiol. 38: 46-58

Laanbroek, H. J., Veldkamp, H. (1982). Microbial interactions in sediment communities. Phil. Trans. R. Soc. B Biol. Sci. 297: 533-550

Lasserre, P., Renaud-Mornant, J. (1973). Resistance and respiratory physiology of intertidal meiofauna to oxygendeficiency. Neth. J. Sea Res. 7: 290-302

Maguire, C. (1977). Meiofaunal community structure and vertical distribution: a comparison of some Co. Down beaches. In: Keegan, B. F., Ceidigh, P. O., Boaden, P. J. S. (ed.) Biology of benthic organisms. Pergamon Press, New York, p. 425-431

Myers, A. C. (1972). Tube-worm-sediment relationships of Diopatra cuprea (Polychaeta: Onuphidae). Mar. Biol. 17: $350-356$

Nedwell, D. B., Abram, J. W. (1978). Bacterial sulphate reduction in relation to sulphur geochemistry in two contrasting areas of saltmarsh sediment. Estuar. coast. mar. Sci. 6 : 341-351

Novitsky, J A., Kepkay, P. E. (1981). Patterns of microbial heterotrophy through changing environments in a marine sediment. Mar. Ecol. Prog. Ser. 4: 1-7

Nuss, B. (1984). Ultrastrukturelle und ökophysiologische Untersuchungen an kristalloiden Einschlüssen der Muskeln eines sulfidtoleranten limnischen Nematoden (Tobrilus gracilis). Veröff. Inst. Meeresforsch. Bremerhaven $20: 3-15$

Ott, J. A., Machan, R. (1971). Dynamics of climatic parameters in intertidal sediments. Thalassia jugosl. 7: 219-229

Pörtner, H. O., Heisler, N., Grieshaber, M. K. (1985). Oxygen 
consumption and mode of energy production in the intertidal worm Sipunculus nudus L.: definition and characterization of the critical $\mathrm{P}_{\mathrm{O}_{2}}$ for an oxyconformer. Respir. Physiol. 59: 361-377

Powell, E. N. (1977). Particle size selection and sediment reworking in a funnel feeder, Leptosynapta tenuis (Holothuroidea, Synaptidae). Int. Revue ges. Hydrobiol. 62: 385-408

Powell, E. N., Bright, T J. (1981). A thioblos does exist gnathostomulid domination of the canyon community at the East Flower Garden brine seep. Int. Revue ges. Hydrobiol. 66: 675-683

Powell, E. N., Bright, T. J., Woods, A., Gittings, S. (1983). Meiofauna and the thiobios in the East Flower Garden brine seep. Mar. Biol. 73: 269-283

Powell, E. N., Crenshaw, M. A., Rieger, R. M. (1979). Adaptations to sulfide in the meiofauna of the sulfide system. I. ${ }^{35}$ S-sulfide accumulation and the presence of a sulfide detoxification system. J. exp. mar. Biol. Ecol. 37: 57-76

Powell, E. N., Crenshaw, M. A., Rieger, R. M. (1980). Adaptations to sulfide in sulfide-system meiofauna. End products of sulfide detoxification in three turbellarians and a gastrotrich. Mar. Ecol. Prog. Ser. 2: 169-177

Powell, M. A., Somero, G. N. (1985). Sulfide oxidation occurs in the animal tissue of the gutless clam, Solemya reidi. Biol. Bull mar. biol. Lab., Woods Hole 169: 164-181

Ray, A. J., Aller, R. C. (1985). Physical irrigation of relict burrows: implications for sediment chemistry. Mar. Geol. 62: $371-379$

Reise, K. (1981a). Gnathostomulida abundant alongside polychaete burrows. Mar Ecol. Prog. Ser. 6: 329-333

Reise, K. (1981b). High abundance of small zoobenthos around biogenic structures in tidal sediments of the Wadden Sea. Helgoländer Meeresunters. 34: 413-425

Reise, K. (1983). Experimental removal of lugworms from marine sand affects small zoobenthos. Mar. Biol. 74: $327-332$

Reise, K. (1984). Free-living Platyhelminthes (Turbellaria) of a marine sand flat: an ecological study. Mikrofauna marina 1: 1-62

Reise, K., Ax, P. (1979). A meiofaunal 'thiobios' limited to the anaerobic sulfide system of marine sand does not exist. Mar. Biol. 54: 225-237

Revsbech, N. P. (1983). In-situ measurement of oxygen profiles of sediments by use of oxygen micro-electrodes. In: Gnaiger, E., Forstner, H. (ed.) Polarographic oxygen sensors. Springer Verlag, Berlin, p. 265-273

Revsbech, N. P., Jørgensen, B. B., Blackburn, T. H., Cohen, Y.
(1983). Microelectrode studies of the photosynthesis and $\mathrm{O}_{2}, \mathrm{H}_{2} \mathrm{~S}$, and $\mathrm{pH}$ profiles of a microbial mat. Limnol. Oceanogr. 28: 1062-1074

Revsbech, N. P., Sørensen, J., Blackburn, T H., Lomholt, J. P. (1980). Distribution of oxygen in marine sediments measured with microelectrodes. Limnol. Oceanogr. 25: 403-411

Revsbech, N. P., Ward, D. M. (1983). Oxygen microelectrode that is insensitive to medium chemical composition: use in an acid microbial mat dominated by Cyanidium caldarium. Appl. environ. Microbiol. 45: 755-759

Revsbech, N. P., Ward, D. M. (1984). Microprofiles of dissolved substances and photosynthesis in microbial mats measured with microelectrodes. In: Cohen, Y., Castenholz, R. W. Halvorson, H. W. (ed.) Microbial mats: stromatolites. Alan R. Liss Inc., New York, p. 171-188

Rhoads, D. C., Morse, J. W. (1971). Evolutionary and ecologic significance of oxygen-deficient marine basins. Lethaia 4 : $413-428$

Savrda, C. E., Bottjer, D. J., Gorsline, D. S. (1984). Development of a comprehensive oxygen-deficient marine biofacies model: evidence from Santa Monica, San Pedro, and Santa Barbara Basins, California Continental Borderland. Bull. Am. Ass. Petrol. Geol. 68: 1179-1192

Sørensen, J., Jørgensen, B. B., Revsbech, N. P (1979). A comparison of oxygen, nitrate, and sulfate respiration in coastal marine sediments. Microb. Ecol. 5: 105-115

Sterrer, W., Rieger, R. (1974). Retronectidae - a new cosmopolitan marine family of Catenulida (Turbellaria). In: Riser, N., Morse, M. (ed.) The biology of the Turbellaria. McGraw-Hill Book Co., New York, p. 63-92

Thistle, D., Sherman, K. M. (1985). The nematode fauna of a deep-sea site exposed to strong near-bottom currents. Deep Sea Res. 32: 1077-1088

Thompson, J. B., Mullins, H. T., Newton, C. R., Vercoutere, T. L. (1985). Alternative biofacies model for dysaerobic communities. Lethaia 18: 167-179

Warwick, R. M., Price, R. (1979). Ecological and metabolic studies on free-living nematodes from an estuarine mud flat. Estuar. coast. mar. Sci. 9: 257-271

Watzin, M. C. (1985). Interactions among temporary and permanent meiofauna: observations on the feeding and behavior of selected taxa. Biol. Bull. mar. biol. Lab., Woods Hole 169: 397-416

Wieser, W., Ott, J., Schiemer, F., Gnaiger, E. (1974). An ecophysiological study of some meiofauna species inhabiting a sandy beach at Bermuda. Mar. Biol, 26: $235-248$

This article was submitted to the editor; it was accepted on November 4, 1986 